\title{
Innenfor og utenfor - innsnevringer og utvidelser av slektsarveretten i Norden i de siste 100 år
}

\author{
John Asland
}

John Asland er cand.jur. (2002) og ph.d. (2008). Han har vært professor ved Institutt for privatrett siden $2012 \mathrm{og}$ instituttleder fra 2019. Asland er hovedredaktør i Tidsskrift for familierett, arverett og barnevernrettslige spørsmål.

E-post: john.asland@jus.uio.no

Artikkelen gir en historisk redegjørelse for begrensninger i slektsarveretten og endringene i arveretten for barn født utenfor ekteskap og barn som er adoptert i Norden, i de siste hundre årene. Avslutningsvis settes utviklingen i de nordiske landene inn i en kontekst av internasjonale menneskerettigheter, som både styrer retningen på rettsutviklingen og som setter rammer for hvilken retning rettsutviklingen kan ta.

Stikkord: arverett, komparativ rett, adopsjon, EMK

\section{Innledning}

Dette nummeret av FAB vier plass til temaer med fellesnevneren nordisk familierett i de siste 100 år. Det er klare forbindelseslinjer mellom familieretten og arveretten. Den viktigste forbindelseslinjen er at de som loven utpeker som arvinger, også er arvelaterens nærmeste familie. I løpet av det siste hundreåret har slektsarveretten blitt betydelig innskrenket $\mathrm{i}$ alle de nordiske landene. Samtidig er personer som tidligere stod utenfor det arverettslige fellesskapet, sluppet inn i varmen. Dette gjelder barn født utenfor ekteskap og barn som arvelateren har adoptert. I denne artikkelen ser jeg nærmere på utviklingen av og begrunnelsen for hvem som utpekes som slektsarvinger i nordisk arvelovgivning - med andre ord hvem som tilhører den arverettslig relevante familien. ${ }^{1}$

Et tilgrensende utviklingstrekk, som tiden og rammene for artikkelen dessverre ikke strekker til for å dekke, er den gradvise styrkingen av ektefellens og etter hvert samboerens arverettslige stilling. Denne utviklingen har pågått parallelt med endringene i slektsarveretten. Til sammen har disse utviklingstrekkene ført til at legalarveretten har gått fra å være en rett for slekten til å bli en rett for en snevrere familiekrets - primært kjernefamilien.

Familieretten har vært preget av et omfattende nordisk lovsamarbeid som blant annet førte til en i stor grad ensartet ekteskapslovgivning og vergemålslovgivning på 1920-tallet. Lovene var bygget opp på samme måte, og de inneholdt i store trekk de samme reglene i en ensartet utforming. ${ }^{2}$ Det ble aldri en felles nordisk arvelovgivning. Det var riktignok nordisk samarbeid også på arverettens område i kjølvannet av samarbeidet på familierettsområdet. Dette førte til Nordisk konvensjon om arv og dødsboskifte 19. november 1934 og at man fikk nye lover og lovendringer i de nordiske landene på arverettens område på 1920- og -30-tallet. ${ }^{3}$

\footnotetext{
${ }^{1}$ Jeg vil rette en stor takk til advokat Pekke Tuunainen og professor Göran Lind for nyttige opplysninger om rettstilstanden i Finland og Sverige.

${ }^{2}$ Se Inge Lorange Backer, Styrket nordisk lovsamarbeid. Muligheter og utfordringer, Nordisk ministerråd, København, 2018, s. 17.

${ }^{3}$ Se lag 8. juni 1928 om arv, lag 30. april 1930 om testamenter og om arvsavtal og lag 9. juni 1933 om boutredning och arvskifte (Sverige); lov 4. juli 1927 om uskiftet bo, lov 21. februar 1930 om skifte og lov 25. juni 1937 nr. 12 om forandringer i arveloven (Norge); og lov om uskifte (Danmark). Se om de nordiske
} 
Det var også et utstrakt samarbeid mellom ekspertkomiteene som utarbeidet forslag til ny arvelovgivning i de nordiske landene på 1950- og -60-tallet. ${ }^{4}$ Sporene er tydeligst i utvalgenes innstillinger og lovforslag. Den nordiske stemmen avtar i styrke i den departementale og parlamentariske lovbehandlingen. Idéutvekslingen i lovforberedelsesstadiet kan imidlertid være viktig i seg selv. Backer skriver følgende i sin utredning om nordisk lovsamarbeid:

«Lovsamarbeid kan ha forskjellige ambisjonsnivåer og mål. Det kan gå ut på å utveksle informasjon og erfaringer, foreta en felles kartlegging og analyse av problemene og utarbeide forslag til lovregler som i større eller mindre grad blir ens i alle landene. Lovsamarbeidet kan også gå ut på at man i nordisk fellesskap får evaluert lovgivningen om visse spørsmål, og en slik evaluering kan føre til initiativ til ny lovgivning.» 5

Selv om det aldri ble noen fellesnordisk arverett, har utviklingen - i hvert fall på de områdene som behandles i denne artikkelen - gått i samme retning. Skrittene er tatt til litt ulik tid og med litt ulik skrittlengde, men den arverettslige familien har i store trekk de samme familiemedlemmer og den samme innbyrdes prioritering i de fem nordiske landene.

\section{Slektsarverettens grenser}

\subsection{Innledning}

Slektsarveretten i de nordiske landene kjennetegnes ved at den er skarpere tilskåret enn i mange andre land. I Sverige, Danmark, Finland og på Island er de fjerneste slektsarvingene arvelaterens onkler og tanter, ${ }^{6}$ mens legalarveretten i Norge også omfatter arvelaterens fettere og kusiner. ${ }^{7}$ Som et motstykke til den nordiske modellen kan nevnes tysk arverett, hvor slektsarveretten i prinsippet er ubegrenset. ${ }^{8}$

I dag er slektsarveretten i alle de nordiske landene tuftet på to grunnleggende prinsipper: parentelprinsippet og representasjonsprinsippet.

Parentelprinsippet går ut på at arven i første rekke tilfaller arvelaterens eget parentel eller arvegangsklasse, dvs. de som nedstammer fra arvelateren selv (livsarvingene eller descendentene). Arvelaterens eget parentel kalles gjerne første arvegangsklasse. Arvinger i en fjernere arvegangsklasse arver ikke så lenge det er arvinger i en nærmere arvegangsklasse. Andre arvegangsklasse er arvelaterens foreldre og livsarvinger etter dem (søsken, nevøer og nieser etc.). Tredje arvegangsklasse er arvelaterens besteforeldre og deres etterkommere (onkler og tanter, fettere og kusiner). I prinsippet kan man tenke seg en uendelig rekke av arvegangsklasser, men tredje arvegangsklasse er i dag den ytterste i alle de nordiske landenes arvelovgivning.

\footnotetext{
konvensjonene i Katrine Kjærheim Fredwall, «Nordisk tillit - Nordisk internasjonal privatrett gjennom 100 år», $F A B 2021$ s. [].

${ }^{4}$ Se SOU 1954: 6 s. 5; Betænkning nr. 291/1961 s. 5-6 og Utkast 1962 s. 1-2. Se også Peter Lødrup, Nordisk arverett, København 2002, s. 38-40.

${ }^{5}$ Inge Lorange Backer, Styrket nordisk lovsamarbeid Muligheter og utfordringer, Nordisk ministerråd, København, 2018, s. 10.

${ }^{6}$ For dansk rett, se lov nr. 515 af 6 . juni 2007 Arveloven $\S 3$ stk. 2. For finsk rett, se ärvdabalk 5. februar 1964/40 2. kap. 3 §. For islandsk rett, se Erfdalög, lov nr. 8 av 14. mars $1962 \S 4$. For svensk rett, se ärvdabalk (1958: 637) 2 kap. $3 \S$.

${ }^{7}$ Se lov 14. juni 2019 nr. 21 om arv og dødsboskifte $\S 6$ første ledd andre punktum.

${ }^{8}$ Tysk slektsarverett er basert på parentelsystemet med ulike arvegangsklasser. Det er regler for fordelingen mellom arvinger i første, andre, tredje og fjerde arvegangsklasse i $\S 1924$ til 1928, mens $\S 1929$ hjemler arverett for fjernere arvegangsklasser, og lar fordelingsreglene for fjerde arvegangsklasse gjelde tilsvarende for slike arvinger.
} 
Representasjonsprinsippet innebærer at dersom en arveberettiget slektning dør før arvelateren, trer slektningens barn inn som arving istedenfor den avdøde arvingen. Motstykket til dette er at den eldre generasjonen i linjen utelukker arvinger som er fjernere i samme linje. Dessuten innebærer representasjonsprinsippet at når arven skal deles mellom flere arvinger som representerer en avdød arving høyere opp i linjen, arver de representerende arvingene like mye til sammen som det den avdøde arvingen de representerer, skulle ha fått hvis han eller hun fortsatt var i live. Hvis eksempelvis arvelaterens to barn som begge døde før arvelateren, etterlater seg henholdsvis ett barn og fem barn, vil enebarnet arve halvparten av arvelaterens formue, mens de fem barna i den andre linjen deler på en halvpart og får derved bare en tidel hver av den totale arven. At arven i slike tilfeller deles etter linjer og ikke etter hoder, har vært omdiskutert - særlig i Norge. ${ }^{9}$ Likevel har lovgiveren de gangene spørsmålet har vært debattert, falt ned på at arven skal fordeles etter linjer, uavhengig av hvor mange hoder det er i hver linje. ${ }^{10}$ Dette resultatet har man også kommet til i de andre nordiske landene. ${ }^{11}$

\subsection{Begrensninger i slektsarveretten i Norge}

I den norske arveloven av 1854 var arveretten frem til 1916 ubegrenset i første og andre arvegangsklasse. I de fjernere arvegangsklassene strakte arveretten seg til syvende ledd. Leddene ble regnet slik at hver fødsel som dannet et slektskap mellom arving og arvelater, ble regnet som ett ledd. ${ }^{12}$ Man var beslektet med sine foreldre i første ledd, besteforeldre i andre ledd og onkler og tanter i tredje ledd. Syvende ledd omfattet for eksempel arvelaterens tippoldeforeldres barnebarn (tremenninger av arvelaterens foreldre).

I 1916 ble slektsarveretten beskåret slik at arveretten omfattet beslektede til og med femte ledd, likevel slik at arveretten fortsatt skulle være ubegrenset i direkte oppstigende linje (ascendenter) og i første sidelinje (foreldrenes livsarvinger). ${ }^{13}$ Med den begrensningen som ble gjort, var de fjerneste arvingene i tredje arvegangsklasse barnebarna til arvelaterens fettere og kusiner. I fjerde arvegangsklasse (oldeforeldrenes parentel) ville arvelaterens besteforeldres søsken og deres barn være arveberettigede, men ikke arvinger lenger ned i linjen - som tremenninger og deres etterkommere. I femte arvegangsklasse (tippoldeforeldrenes parentel) ville oldeforeldrenes søsken være arveberettigede, men ikke slektninger lenger ned i linjen.

Begrensningene i slektsarverettens grenser hadde begrunnelser som gikk langs flere akser. Dels var det rent fiskale hensyn - ofte sett i sammenheng med drøftelser av omfanget av arveavgiften. ${ }^{14}$ Hvor det verken var ektefelle, slektsarvinger eller testamentsarvinger, ville

\footnotetext{
${ }^{9}$ Se drøftelser i Utkast 1846 s. 18-19; Ot.prp. nr. 14 (1937) s. 1-3; Innst. O. XI. (1937) s. 1-3; Utkast 1962 s. 46-53; Ot.prp. nr. 36 (1968-69) s. 46; NOU 2014: 1 s. 26-27.

${ }^{10}$ Slik var rettsstillingen i 1854-loven, etter lovendringen i 1937, i 1972-loven, og er det fortsatt i den nåværende arveloven av 2019.

${ }^{11}$ For Danmarks del, se Betænkning nr. 14732006 s. 49-50; Betænkning nr. 291/1961 s. 22-23. Ved arveloven for Grønland, lov nr. 190 av 7. juni 1958, ble det også i Grønland innført en arvedeling etter stammer og linjer, uten unntak for tilfeller hvor arvingene i skifteoppgjøret var ulike linjer av barnebarn med ulikt antall, selv om det var antatt at det tidligere var et prinsipp om deling etter hoder på Grønland i slike tilfeller (se Betænkning nr. 291/1961 s. 23 med videre henvisninger). Det har ikke vært like stor diskusjon om denne problemstillingen i de øvrige nordiske land. Se likevel for islandsk rett Armann Snævarr, «Hovedpunktene i den islandske arvelovgivningen», TfR 1956, s. 322.

${ }^{12}$ Lov om arv 31. juli $1854 \S 2$.

${ }^{13}$ Lov 7. april 1916.

${ }^{14}$ Se Ot.prp. nr. 14 (1937) s. 7.
} 
staten gå inn som arving. ${ }^{15}$ Dette hensynet hadde riktignok forholdsvis liten vekt. ${ }^{16}$

Begrensninger var også begrunnet i at familiefølelsen var svak i de ytterste leddene av slektsarveretten. ${ }^{17}$ Slektsfølelsen ble brukt som et argument både for å opprettholde en vid slektsarverett og til å begrense den. De som ønsket begrensninger, anførte at de ikke kunne forstå hvordan slektsfølelsen kunne svekkes av at lovgiver innskrenket slektsarveretten. De som næret en slik slektsfølelse overfor fjerne slektninger, «hadde jo alltid den utvei at testamentere til sine slegtninger, om han følte sig at staa i nogensomhelst forbindelse med dem». ${ }^{18}$

Praktiske hensyn ble også trukket frem i begrunnelsen for å innsnevre slektsarveretten. Det «vilde befri offentlige institutioner for en masse bryderi, for at lete frem slegtninger, som ikke engang vet, at de har nogen arvelater». ${ }^{19}$ En begrensning av slektsarveretten ville spare offentlige myndigheter for et lite fruktbringende arbeid med å lete opp fraværende fjerne arvinger etter avdøde. De fjerne slektningene kunne dessuten ha forlatt landet. Den store utvandringen til Nord-Amerika og andre fjerne verdensdeler ble trukket frem som et selvstendig argument for innsnevring av slektsarveretten. ${ }^{20}$ For de fjernere slektningene vil dessuten arveloddene bli så små at det ikke står i forhold til den innsats som må til for å oppspore arvingene. Arven kunne bli så liten at arvingen ikke fant det umaken verd å heve arvebeløpet. Pulveriseringshensynet tilsa derfor at man ikke burde utstrekke arveretten til slike ledd hvor antallet arvinger innebar at arveloddene ble ubetydelige. ${ }^{21}$ Det ble også lagt til grunn at folk som bare hadde fjerne slektninger, ofte skrev testament. ${ }^{22}$ Slektsarveretten fikk således karakter av en tilfeldig fordel for slektsarvingene. Allerede i forbindelse med 1916loven ble det antydet at slektsarveretten kanskje burde innsnevres ytterligere, men at man på arverettens område burde gå forsiktig frem. ${ }^{23}$

I 1937 fikk norsk slektsarverett den avgrensning som den har hatt frem til i dag. Fjerde arvegangsklasse (oldeforeldrenes parentel) ble fjernet fra arvetavlen. Tredje arvegangsklasse ble dessuten beskåret slik at bare to ledd av livsarvinger etter arvelaterens besteforeldre ble omfattet. Fettere og kusiner beholdt legalarveretten, men deres barn var avskåret. For beskjæringen av fjerde arvegangsklasse var det særlig fremhevet at oldeforeldrene selv sjelden ville ta arv, og at hensynet til å bevare eiendom i slekten hadde liten vekt da det var så mange linjer av oldeforeldre. Beskjæringen i tredje arvegangsklasse var særlig begrunnet i at når arven skulle fordeles mellom avkom av fettere og kusiner, ville den pulverisert.

Gjennomsnittlig antall fettere og kusiner var på denne tiden 24, mens antallet barn av fettere og kusiner gjennomsnittlig utgjorde 96 personer. $^{24}$

\subsection{Begrensninger i slektsarveretten i Sverige}

Frem til 1920-tallet var svensk arverett fortsatt regulert av 1734 års lag, hvor slektsarveretten ikke var begrenset til visse parenteler eller ledd. Den strakte seg så langt det var slektninger. Det var først hvis man ikke kunne finne noen slektninger, og arvelateren heller ikke etterlot

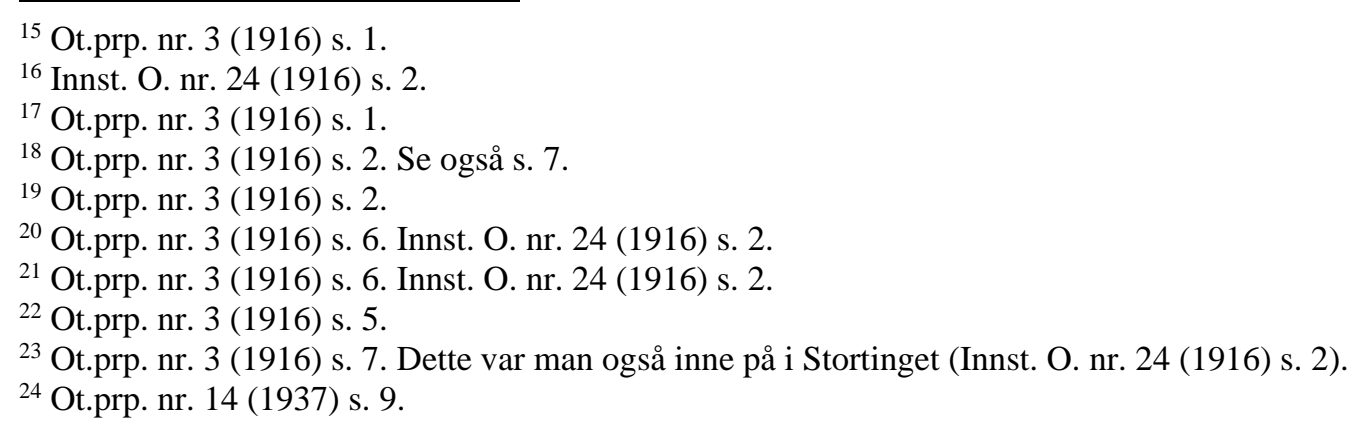


seg ektefelle, at arven tilfalt staten. Arvetavlen i 1734 års lag var forholdsvis innviklet med en kombinasjon av parentelsystem og gradualsystem. ${ }^{25}$

Med arvslagen av 8. juni 1928 ble det gjort betydelige innskrenkninger i slektsarveretten. Lovens kapittel $1 \mathrm{om}$ slektens arverett bygde på parentelsystemet og representasjonsprinsippet. Den hadde tre arvegangsklasser. Første arvegangsklasse omfattet arvelaterens livsarvinger. Andre arvegangsklasse omfattet arvelaterens foreldre og deres etterkommere, mens tredje arvegangsklasse omfattet besteforeldrene og deres barn. Mens første og andre arvegangsklasse gikk ubegrenset nedad, stoppet tredje arvegangsklasse ved besteforeldrenes barn (arvelaterens onkler og tanter).

Det var et stort skritt å gå fra en ubegrenset arverett for slekten til en arverett for en ganske snevert avgrenset krets av slektninger. Lagberedningen var imidlertid av den oppfatning at det var «av större principiell betydelse att över huvud fastställa en arvrättsgräns än att bestämma, var inom skyldskapsordningen denna gräns skall dragas». ${ }^{26}$

Lovutredningen redegjorde for en rekke teorier om arverett. ${ }^{27}$ Etter redegjørelsen for arveteori og lovendringer og lovforslag i andre land oppsummeres grunnlaget for endringer slik:
«Först då arvsrättens grund förläggas icke till skyldskapen så som sådan utan till den sociala ock ekonomiska samhörighet, varom skyldskapskänslan regelmässigt bär vittne, uppstår utrymme för en arvslagstiftning, som kan följa rättsutvecklingen i det hela. Med skyldskapen är historiskt förknippad känslan av ekonomisk ock social samhörighet. Känslan av dylik på skyldskap grundad samhörighet växlar hos skilda folk ock under olika tider i samband med samhällens skiftande organisation, men har i nyare tid överhuvud en tendens att avtaga med samfärdsmedlens utveckling ock det ekonomiska livets gång från naturalhushållning till penninghushållning. I den mån denna samhörighetskänsla mellan skyldemän försvagats, är en förändring av arvslagarna påkallad.» ${ }^{28}$

Utredningen hadde liten tro på fiskale hensyn som begrunnelse for innskrenkninger av slektsarveretten. Det ble påpekt at særdeles sterke begrensninger måtte til før en begrensning av slektsarveretten skulle tilføre staten midler av betydning. ${ }^{29}$ Det ble også fremhevet at fiskale begrunnelser for innsnevring av slektsarveretten kunne fremstå som statlig konfiskasjon, og at slike begrunnelser hadde vist liten evne til å slå gjennom i opinionen. ${ }^{30}$ For den svenske Lagberedningen var rettstekniske hensyn som problemene med å oppspore fjerne slektninger som hadde emigrert til fjerne land, kun støtteargumenter. ${ }^{31}$

Etter den svenske lovutredningens syn var ikke de begrensninger som var gjort i en del land, for eksempel den norske begrensningen fra 1916 og tilsvarende endringer i Frankrike, Spania, Italia og Nederland, tilstrekkelig til at arverettens utstrekning kom i overensstemmelse med de endringer som var skjedd i samfunnet i sosioøkonomisk henseende. ${ }^{32}$

Utredningen gikk systematisk til verk. Det ble innhentet tall gjennom Statistiska Centralbyrån (SCB) over skifteprotokollene for årene 1919 og 1920. Ut fra dette materialet ble det laget tabeller som viste forekomsten av arverett ut fra slektskapet mellom avdøde og arvingene. Det

\footnotetext{
${ }^{25}$ Se nærmere SOU 1925: 43 s. 61-62.

${ }^{26}$ SOU 1925: 43 s. 64.

${ }^{27}$ SOU 1925: 43 s. 64 flg.

${ }^{28}$ SOU 1925: 43 s. 92.

${ }^{29}$ SOU 1925: 43 s. 91.

${ }^{30}$ SOU 1925: 43 s. 92 og s. 108.

${ }^{31}$ SOU 1925: 43 s. 106.

${ }^{32}$ SOU 1925: 43 s. 94.
} 
ble også ført statistikk over forekomsten av testament i de ulike grupperingene og fordelingen mellom testamentarv og legalarv. Tallene fra SCB ble bearbeidet videre i utredningen. ${ }^{33}$ Tilfeller hvor det var arvinger i tredje arvegangsklasse eller fjernere, utgjorde kun 1,9\% av dødsboene i 1919 og 2,4 \% i 1920. Andelen av den totale arven var langt lavere, noe som tilsa at det var en høy testamentfrekvens blant arvelatere som kun hadde fjerne slektsarvinger. Etter utredningens syn underbygget statistikken grunnlaget for legalarverett for første og andre arvegangsklasse, mens det var svakere grunnlag for arverett for tredje arvegangsklasse og fjernere slektninger. Slike arvinger ble i stor grad ble valgt bort gjennom testament. ${ }^{34}$

Det fremheves som arverettens oppgave å fremme den $\varnothing$ konomiske og sosiale kontinuiteten mellom arvelateren og arvingen. ${ }^{35}$ Dette grunnlaget er sterkest mellom arvelateren og descendentene, og det avtar overfor ascendenter og arvinger i sidelinjene. Slektskap alene skulle ikke være grunnlag for legalarverett. Arverett burde bare forekomme der slektsfølelsen har grunnlag i en sosial og økonomisk samhørighet mellom arvelater og arving.

Som ledd i argumentasjonen for begrensninger i slektsarveretten ble det påpekt at samfunnet har overtatt mange av de funksjoner som slekten tidligere hadde. Dette gjelder alt fra straffeog prosessrett til sosialomsorg og landbruk. De slektninger som burde utelukkes fra slektsarveretten, var slike som man regelmessig kunne anta manglet den sosiale og økonomiske tilhørighet som arveretten hviler på. ${ }^{36}$ Arverettens avgrensning burde bygge på de bestående bånd mellom arvelater og arving, ikke være en brekkstang for å svekke bestående bånd eller gjenoppvekke bånd som ikke lenger var der. Grensen burde trekkes på en måte som ikke ville medføre en vesentlig $\varnothing \mathrm{kning} i$ antallet testamenter som tilgodeså slektninger som var utelukket fra legalarv. ${ }^{37}$ Arverettens berettigelse var sterkest for livsarvingene. Der var den økonomiske og sosiale kontinuiteten mellom arvelater og arving udiskutabel. ${ }^{38}$ Den dypt rotfestede samhørigheten mellom foreldre og barn tilsa også at foreldre burde ha arverett etter sine barn. Foreldrene hadde gjennom sin oppfostring av barna regelmessig også gjort store $\varnothing$ konomiske oppofringer overfor barna. I mange tilfeller ville foreldrenes arverett bare innebære en tilbakeføring av midler som tidligere hadde gått fra foreldrene til barna. ${ }^{39}$ Lagberedningen var også av den oppfatning at søsken hadde en naturlig plass på lovens arvetavle. Søsken var regelmessig oppvokst i samme hjem, og de ville gjerne føle en naturlig forpliktelse til å hjelpe og støtte hverandre. Søsken var også ofte sameiere i eiendom som var arvet etter foreldrene. ${ }^{40}$ Arverett for nevøer og nieser ble begrunnet $\mathrm{i}$ at for arvelatere uten egne livsarvinger ville familietilknytningen føles sterkere overfor søsknenes livsarvinger enn når arvelateren hadde egne barn. Disse familiebåndene ville være særlig sterke i tilfeller hvor arvelaterens søsken var døde, slik at søsknenes barn var blitt foreldreløse. Det var i disse situasjonene at arverett for søskens etterkommere var aktuelt.

\footnotetext{
${ }^{33}$ SOU 1925: 43 s. 95 flg. Som en kuriositet kan nevnes at antallet dødsbo i 1919 var 32,3 \% høyere enn i 2020 , noe som ble tilskrevet spanskesyken som medførte stor overdødelighet både i siste halvår i 1918 og i 1919.

${ }^{34}$ SOU 1925: 43 s. 99-100.

${ }^{35}$ SOU 1925: 43 s. 104.

${ }^{36}$ SOU 1925: 43 s. 109.

${ }^{37}$ SOU 1925: 43 s. 109.

${ }^{38}$ SOU 1925: 43 s. 110-111.

${ }^{39}$ SOU 1925: 43 s. 111.

${ }^{40}$ SOU 1925: 43 s. 111-112.
} 
Testamentspraksis viste at søsken og søskens etterkommere i liten grad ble valgt bort av arvelateren. ${ }^{41}$

Lagberedningen la til grunn at besteforeldre svært sjelden arvet sine barnebarn, men at det ville oppleves som støtende hvis de ikke var arveberettiget i tilfeller hvor de var de nærmeste gjenlevende slektningene. Hvor besteforeldre var arvinger, ville dessuten arvelateren ofte være mindreårig, slik at det ikke var noe testament man kunne falle tilbake på. I slike tilfeller ville dessuten ofte mye av midlene som arvelateren etterlot seg, stamme fra arv etter foreldrene eller understøttelse fra besteforeldrene. Det samme argument kunne anføres for arverett for oldeforeldre, men denne gruppen av arvinger var så liten at man la til grunn at de få tilfeller hvor det var aktuelt, kunne løses gjennom ettergivelse av arv som ellers ville gå til staten eller til det arvefond som lagberedningen foreslo. ${ }^{42}$

Lagberedningen var i tvil om onkler og tanter fortsatt burde ha plass på lovens arvetavle, men kom under tvil at det fortsatt var et visst behov for det ut fra de sosialøkonomiske forholdene i landbefolkningen. ${ }^{43}$ For fettere og kusiner mente Lagberedningen at den sosialøkonomiske samhørigheten var for svak for å begrunne legalarverett. Statistikken viste også at fettere og kusiner i stor grad ble valgt bort av arvelateren gjennom testament. Testamentspraksis kunne ses som et uttrykk for at beskjæring av fettere og kusiner fra lovens arvetavle ikke var i strid med den alminnelige rettsoppfatning. ${ }^{44}$ Som et sideargument ble det også vist til at den arv som fettere og kusiner fikk i de tilfeller hvor de ble kalt til arv, regelmessig var så liten at den ikke hadde nevneverdig $\varnothing$ konomisk nytte for dem. At en beskjæring av tredje arvegangsklasse innebar et innhugg i parentelprinsippet, ble ikke ansett som en avgjørende innvending.

I ärvdabalken fra 1958 er den avgrensningen som man kom frem til i 1928, opprettholdt. ${ }^{45}$ Det var ingen diskusjon om å gjøre endringer i avgrensningene av slektsarveretten i arbeidet som ledet frem mot ärvdabalken.

\subsection{Begrensninger i slektsarveretten i Danmark}

I Danmark strakte arveretten etter arverettsforordningen av 1845 seg meget langt. Det var fem arvegangsklasser. I samtlige arvegangsklasser var det representasjonsrett så langt nedover som det var etterkommere, riktignok med den begrensning at arven ikke gikk videre enn til syvende mann, jf. Christian Vs danske lov 5-211. «Syvende Mand» måtte trolig forstås på samme måte som «syvende ledd» i den norske arveloven av $1854 .{ }^{46}$

I kommisjonsbetenkningen fra 1941 ble det argumentert langs samme linjer som i Norge og i Sverige for å begrense utstrekningen av slektsarveretten. Det ble vist til at en så vid slektsarverett ikke stod i noe rimelig forhold til den betydning slekten hadde i det danske samfunnet på 1940-tallet. I de ytterste arvegangsklassene kunne slektningene som var berettiget til arv, være så fjerne at verken arvelateren eller arvingen var klar over slektskapsforholdet. Å finne disse arvingene kunne også ofte by på store vanskeligheter som ikke stod i forhold til de relativt små arvelodder som skulle utdeles til den enkelte arving. Forslaget gikk ut på å fjerne fjerde og femte arvegangsklasse, og at tredje arvegangsklasse

\footnotetext{
${ }^{41}$ SOU 1925: 43 s. 112.

${ }^{42}$ SOU 1925: 43 s. 112.

${ }^{43}$ SOU 1925: 43 s. 112-113.

${ }^{44}$ SOU 1925: 43 s. 113.

${ }^{45}$ Se ärvdabalken 2. kap.

${ }^{46}$ Se ovenfor i punkt 2.2 .
} 
skulle kuttes av etter besteforeldrenes barn, slik at onkler og tanter skulle være de siste arveberettigede slektningene. ${ }^{47}$

I 1954 ble det i tråd med kommisjonsutkastet fra 1941 gjort vesentlige innsnevringer av lovens arvetavle. ${ }^{48}$ Fjerde og femte arvegangsklasse (oldeforeldrenes og tippoldeforeldrenes parenteler) ble strøket fra arvetavlen. Tredje arvegangsklasse ble dessuten beskåret, slik at bare besteforeldrene og besteforeldrenes barn og barnebarn (onkler og tanter, fettere og kusiner) gjenstod. Fettere og kusiner overlevde beskjæringen i 1954, ut fra en tanke om at slektsfølelsen, særlig på landet, fortsatt var for sterk til å utelukke dem. ${ }^{49}$ Det gikk likevel ikke lang tid før også fettere og kusiner forsvant fra arvetavlen. Allerede ved arveloven av1963 forsvant også fettere og kusiner fra arvetavlen. I arvelovsbetenkningen i 1961 ble det vist til at innskrenkningen i Sverige i 1928 hvor også fettere og kusiner ble fjernet fra arvetavlen, ikke hadde blitt utsatt for kritikk. ${ }^{50}$ Det ble også vist til at en tilsvarende beskjæring av tredje arvegangsklasse i den islandske arveloven av 1949 heller ikke hadde ført til kritikk eller vanskeligheter. ${ }^{51}$

Selv om slektsarverettens grenser var endret så sent som i 1954, mente utvalget i 1961 at man ved en totalrevisjon av arveloven måtte ta spørsmålet opp til fornyet vurdering. Etter utvalgets syn var avgrensningen som var foreslått av kommisjonen i 1941 og av regjeringen i 1953, den rette. Det ble anført at selv om slektsfølelsen mellom fettere og kusiner kunne være sterk i barne- og ungdomsårene, ville den avta i voksen alder. Det ble også vist til at arverett for fettere og kusiner i praksis hadde liten betydning (det utgjorde mellom 1 og $2 \%$ av den totale arvemassen), og at det kunne by på store praktiske utfordringer å finne frem til arvingene, som også kunne være spredd i forskjellige land. Utvalget mente at testamentsbyrden burde hvile på arvelatere som ønsket å tilgodese fettere og kusiner, og at arvelateren da også kunne utpeke fettere og kusiner som han eller hun fortsatt hadde kontakt med. ${ }^{52}$

Dagens danske arvelov av 2007 har i $\S \S 1$ til 3 den samme avgrensning av slektens arverett som i loven fra 1963.

\subsection{Begrensninger i slektsarveretten på Island}

Island hadde frem til 1949 en arveforordning av 25. september 1850 som i det alt vesentlige stemte overens med den danske arverettsforordningen av 1845 - herunder en vid slektsarverett. Island fikk ny arvelov i 1949, som bygde på det danske kommisjonsutkastet fra 1941 med vesentlige beskjæringer av slektsarveretten. ${ }^{53}$ Et særtrekk ved den islandske arveloven av 1949 var at andre arvegangsklasse var begrenset nedad, slik at den ikke strakte seg lenger enn til nevøer og nieser. Etterkommere etter nevøer og nieser var ikke arveberettiget. ${ }^{54}$ Den gjeldende islandske arveloven er fra $1962 .{ }^{55}$ I denne loven er slektsarveretten avgrenset på samme måte som i dansk rett. Det er ingen begrensninger nedover i andre arvegangsklasse, mens tredje arvegangsklasse kun inkluderer besteforeldre og onkler og tanter. ${ }^{56}$

\footnotetext{
${ }^{47}$ Betænkning 1941 særlig s. 31 og 37.

${ }^{48}$ Lov nr. 66 af 17. marts 1954 om ændringer i arveforordningen (arveklasserne).

${ }^{49}$ Folketingstidende $1953-54$ s. 249-250.

${ }^{50}$ Betænkning 291/1961 s. 24.

${ }^{51}$ Betænkning 291/1961 s. 24.

52 Betænkning 291/1961 s. 25.

${ }^{53}$ Lov 25. mai 1949.

${ }^{54}$ Armann Snævarr, «Hovedpunktene i den islandske arvelovgivningen, TfR 1956, s. 325.

${ }^{55}$ Lov nr. 8, 14. mars 1962.

${ }^{56}$ Lov nr. 8, 14. mars $1962 \S 4$.
} 


\subsection{Begrensninger i slektsarveretten i Finland}

Finsk arverett var regulert av 1734 års lag helt til denne loven for arverettens vedkommende ble avløst av ärvdabalken i 1965. Det var riktignok gjort enkelte endringer i arveretten, som innføring av lik arverett for menn og kvinner. Arvelovgivningen hadde også vært under revisjon helt siden 1930-tallet. Det var imidlertid ikke gjort noen endringer i utstrekningen av slektsarveretten, selv om dette var foreslått både i 1935 og i 1938, og også var lagt til grunn av Lagberedningen i 1955. ${ }^{57}$

I den finske ärvdabalken 2. kapittel er slektsarveretten avgrenset slik at de siste arveberettigede slektningene er onkler og tanter i tredje arvegangsklasse.

\section{Arverett for barn født utenfor ekteskap}

\subsection{Innledning}

Til tross for at slektsarveretten strakte seg langt i de nordiske landene på begynnelsen av 1900-tallet, var det en gruppe av slektninger som glimret med sitt fravær, i hvert fall som arvinger etter faren og farsslekten, nemlig barn som var født utenfor ekteskap.

\subsection{Norge}

Norge var først ute i verden med å likestille barn født i og utenfor ekteskap med hensyn til arv etter faren og farsslekten. Dette var et ledd i de såkalte Castbergske barnelover fra 1915, som trådte i kraft 1. januar 1917. ${ }^{58}$ Med denne lovreformen fikk barn av foreldre som ikke var gift med hverandre, samme arverett som barn som var født innenfor ekteskap. Før 1917 var farsarv for barn født utenfor ekteskap avhengig av testament eller at faren lyste barnet i kull og kjønn. ${ }^{59}$ De nye arvereglene fikk bare virkning fremover, dvs. for barn som var født etter 1 . januar $1917 .{ }^{60}$

Barn født utenfor ekteskap hadde helt siden Christian Vs Norske Lov hatt arverett etter moren og morsslekten. ${ }^{61}$ I Norske Lov var det et unntak fra arverett etter moren og morsslekten hvis barnet var resultat av et incestuøst forhold eller at moren ved unnfangelsen hadde gjort seg skyldig i utroskap. Dette unntaket ble opphevet i $1892 .{ }^{62}$

At barn født utenfor ekteskap skulle arve faren, ble under arbeidet med arveloven av 1854 avvist med begrunnelse $\mathrm{i}$ at bevisene for farskap var for svake til å utløse arverett når faren ikke hadde anerkjent barnet, og dessuten at man ikke kjente en slik arverett i noe sivilisert lands lovgivning. ${ }^{63}$ Tiden var heller ikke moden i 1892 for arverett etter faren og farsslekten.

\footnotetext{
${ }^{57}$ SOU 1925: 43 s. 92.

${ }^{58}$ Det var i alt seks lover som til sammen hadde til formål å styrke rettighetene til ugifte mødre og deres barn. Lovendringen i arveloven var lov 10. april $1915 \mathrm{nr} .4 \mathrm{om}$ forandringer i lov om arv av 31. juli 1854 med tillægslov av 27. juni 1892. Det er utførlig redegjort for de Castbergske barnelover og bakgrunnen for dem i Geir Kjell Andersland (red.), De castbergske barnelover 1915-2015, Oslo, 2015, og Marion Holthe Hirst, De Castbergske barnelover fra 1915 - et norsk fфrsteskritt i rettsutviklingen, Oslo 2015.

${ }^{59}$ Lov 31. juli $1854 \S 5$.

${ }^{60}$ Se lov 10. april 1915 (nr. 4) §5.

${ }^{61}$ NL 5-2-73.

${ }^{62}$ Lov 27. juni 1892 indeholdende Forandring i Arveloven af 31te Juli 1854. Se nærmere om loven i Hirst, op.cit., s. 7-13.

${ }^{63}$ Se Hirst, op.cit., s. 9.
} 
Departementet sluttet seg den gang til høringsuttalelse fra magistraten i Namsos, som påpekte at å bli født utenfor ekteskap var noe man like lite kan påklage som at man var født fattig. ${ }^{64}$

I årene etter 1892 ble det stadig fremmet krav om nye reformer som skulle stille barn født utenfor ekteskap og deres mødre bedre. Dette ble dels begrunnet i de elendige kår mange av disse barna og deres mødre levde under. Justisdepartementet ba i 1906 Statistisk sentralbyrå om å innhente opplysninger om levekårene. Rapporten som kom i 1907, var dyster lesning. Blant annet var spedbarnsdødeligheten meget høy sammenlignet med dødeligheten blant barn født i ekteskap. Av sammenlignbare land var det bare Danmark som var dårligere stilt enn Norge på dette området. ${ }^{65}$ Rapporten satte fart i arbeidet. Det ble i de påfølgende år fremmet flere forslag om reformer på dette området. Særlig aktiv var Johan Castberg, dels som stortingsmann, dels som statsråd, og dels som representant for interesseorganisasjoner. ${ }^{66}$ Den sentrale argumentasjonen for lovendringene var angitt i Ot.prp. nr. 13 (1909) av Johan Castberg som justisminister. Castberg var også statsråd i regjeringen som fremla de forslagene som ble fremlagt i 1914, og som ledet frem til lovene fra 1915. Da saken kom opp i Stortinget, var Castberg trådt ut av regjeringen og var stortingsrepresentant. Han ble med i justiskomiteen, som med knapt flertall gikk inn for Castbergs linje:

«Komiteens flertal finder saaledes, at propositionen er bygget paa et sundt og retfærdig grundlag. Naar saken først er reist, anser flertallet det umulig at avvise den eller at opretholde og bygge videre paa retsregler, som indeholder en fundamental fornegtelse av princippet like ansvar og pligt for mand og kvinde og for et barns far og mor.» ${ }^{67}$

I stortingsdebatten var det høy temperatur. Motstanderne av forslaget mente at lovendringene ville undergrave ekteskapet som institusjon. ${ }^{68}$ Til dette responderte Castberg at det som «krænker egteskapet, er de handlinger som begaaes, det er ikke det at sandheten kommer frem om de handlinger». ${ }^{69}$ Debatten kretset også rundt innholdet i selve familiebegrepet.

Tilhengerne av arverett mente at arveretten burde være uløselig knyttet til blodsbåndet. Motstanderne, representert ved statsminister Gunnar Knudsen, viste til at arveretten knyttet seg til familiebegrepet, ikke blodsbåndet. Etter Knudsens syn var familiebåndet og arveretten knyttet til fellesskap mellom dem som arbeidet og bodde sammen på en eiendom. ${ }^{70}$

Hensynet til barnemoren ble også trukket frem. Motstandere av nyordningen mente at de nødvendige unders $\varnothing$ kelsene for å få brakt farskapet på det rene ville bli et «sedelighetsinkvisitionstribunal» som ville virke brutalt, selv om det hadde gode hensikter. ${ }^{71}$ Tilhengerne mente at moren i de fleste tilfeller ville velge å gå gjennom disse prøvelsene av hensyn til barnet. ${ }^{72}$

For tilhengerne av lovendringen var det en viktig del av begrunnelsen at faren skulle holdes ansvarlig, slik sitatet fra justiskomiteens flertall bærer bud om. Motstanderne av lovendringen var skeptiske til om lovendringene kunne påvirke forholdet mellom faren og barnet i positiv

\footnotetext{
${ }^{64}$ Ot.prp. nr. 10 (1892) s. 33.

${ }^{65}$ Se Hirst, op.cit., s. 17.

${ }^{66}$ Se Hirst, op.cit., s. 18 flg., og Andersland, op.cit., s. 17 flg.

${ }^{67}$ Indst. O. XIII (1914) s. 12.

${ }^{68}$ Hirst, op.cit., s. 43.

${ }^{69}$ Forhandlinger i Odelstinget for 1915 s. 32.

${ }^{70}$ Forhandlinger i Odelstinget for 1915 s. 161.

${ }^{71}$ Forhandlinger i Lagtinget for 1915 s. 28-29.

${ }^{72}$ Hirst op.cit., s. 50.
} 
retning. Tilhengerne innrømmet at det ikke gikk an å fremtvinge følelser, men at ansvar og pliktoppfyllelse kunne fremtvinges. ${ }^{73}$

Hensynet til barnefarens ektefelle og barn i ekteskap ble også trukket frem. Motstanderne mente at innblanding fra barn født utenfor ekteskapet i arveoppgjøret ville fra ektefellens og de andre barnas side oppleves som «et indbrudd i deres egne velervervede rettigheter». ${ }^{74}$

Moral ble trukket frem av både tilhengere og motstandere av lovendringen. Tilhengere mente at ansvarliggjøring av mannen kunne tøyle mannens seksualmoral, mens motstanderne, som representanten Abrahamsen, var mer pessimistisk: «Vi er paa felter, hvor livets mægtigste kræfter syder og bruser, og hvor man hverken tænker paa underholdsbidrag eller arvespørsmaal.» ${ }^{75}$

Motstandere av arveretten fryktet at kvinnene kunne spekulere i å utpeke velstående menn som far til sine barn, noe tilhengerne var mindre bekymret for:

\footnotetext{
«Det er dog ikke en saa letvindt og liketil og morsom affære, dette at være besvangret og faa barn og bli forpligtet til at ta sig av det, og fostre det op og skaffe det nødvendigste tilveie til det, indtil det blir saa stort, at det kan klare sig selv, at man skulde tro, at det gaar kvinder omkring og spekulerer i dette for at opnaa den tilfældige mulighet dette som staar i det blaa, en arv.» ${ }^{76}$
}

Kronargumentet til motstanderne av arverett var bevisproblemene med å fastslå med sikkerhet hvem som var far til barnet. ${ }^{77} \mathrm{I}$ det store flertall av saker var det ingen tvil om hvem som var far, men i de usikre sakene var det delte oppfatninger om hvor sterke bevis som måtte kreves. Tilhengerne av loven mente at man på dette området, som på mange områder, måtte nøye seg med indisiebevis, mens motstanderne fant det nødvendig med mer håndfaste bevis for å legge til grunn at noen var far når dette også skulle innebære arverett etter faren.

\subsection{Island}

Island fulgte ganske kort tid etter Norge med å likestille barn født innenfor og utenfor ekteskap. Dette ble gjort allerede i 1921 ved innføringen av en ly lov om uektefødte barn. ${ }^{78}$ I islandsk rett fikk barn født etter ikrafttredelsen 1. januar 1922 arverett selv om de var født utenfor ekteskap, så fremt farskapet var brakt på det rene. Ved arveloven av 1949 ble det ikke tatt noe tilsvarende forbehold om at reglene om arverett for barn født utenfor ekteskap ikke hadde tilbakevirkende kraft. Høyesterett kom ved dom 4. juni 1951 til at også uektefødte barn født før 1922 tok arv etter sin far. ${ }^{79}$

\subsection{Danmark}

Danmark fulgte etter sine $\varnothing$ stnordiske naboer og innførte arverett for barn født utenfor ekteskap i $1937 .{ }^{80}$ Lovendringen, som trådte i kraft 1. januar 1938, fikk ikke tilbakevirkende kraft. Arverett etter faren for barn født før 1938 av ugifte foreldre fordret at de enten ble tilgodesett ved testament eller at faren lyste barnet i kull og kjønn. ${ }^{81}$

\footnotetext{
${ }^{73}$ Forhandlinger i Lagtinget for 1915 s. 67.

${ }^{74}$ Forhandlinger i Odelstinget for 1915 s. 160.

${ }^{75}$ Forhandlinger i Odelstinget for 1915 s. 57.

${ }^{76}$ Forhandlinger i Odelstinget for 1915 s. $179 \mathrm{flg}$.

${ }^{77}$ Se nærmere om dette i Hirst, op.cit., s. 61 flg.

${ }^{78}$ Se Armann Snævarr, «Hovedpunktene i den islandske arvelovgivningen», TfR 1956, s. 321-322.

${ }^{79}$ Armann Snævarr, «Hovedpunktene i den islandske arvelovgivningen», TfR 1956 s. 324.

${ }^{80}$ Lov nr. 134 af 7. mai 1937 (arveret for børn uden for ægteskab).

${ }^{81}$ Se nærmere Svend Danielsen, Arveloven, 5. udg., København 2005, s. 31 flg.
} 
Arveretten som barnet fikk etter faren og farsslekten, korresponderte ikke med noen tilsvarende arverett for faren og farsslekten etter barnet. Faren og farens slekt tok bare arv etter barnet i den utstrekning barnet hadde fătt arv eller gave fra farens slekt. Omfanget av arv og gaver fra farens slekt anga yttergrensene for farsslektens arverett. Som gaver skulle bare regnes slikt som ville forøke barnets formue, ikke gaver av ubetydelig verdi eller underholdsbidrag. Det var i realiteten ingen egentlig arverett, men en form for tilbakefallsrett som farsslekten her var avspist med. Begrunnelsen for denne vesentlige begrensningen i arverett for faren og farsslekten var at man ville utelukke at en mann skulle kunne ha noen $\varnothing$ konomisk interesse i å få fastslått farskap til et barn som var født utenfor ekteskap. ${ }^{82}$ Hvis barnet var unnfanget ved nærmere bestemte seksualforbrytelser som faren var straffedømt for, var arverett for faren og farsslekten helt utelukket.

I den danske arvelovsbetenkningen fra 1961 viser utvalget til at det hadde vært gjensidig arverett mellom barnet og faren og farsslekten i Norge siden 1917 og på Island siden 1921 uten at dette hadde gitt anledning til kritikk. Utvalget fant det utvilsomt at barn født utenfor ekteskap fortsatt skulle ha arverett etter faren og farsslekten. Utvalget fant det videre utvilsomt at faren og farsslekten ikke skulle ta arv i tilfeller hvor barnet var unnfanget som følge av nærmere bestemte seksualforbrytelser. Utvalget var mer tvilende til om farens og farsslektens arverett etter barnet fortsatt skulle begrenses til berikelse som var tilfalt barnet fra faren og farsslekten.

Som argument mot full arverett for faren og farsslekten ble det anført at barnet i mange tilfeller ville ha større sosial og økonomisk samhørighet med moren og morsslekten, og at det kunne virke urimelig eller støtende om barnet etter å ha arvet moren dør før det når testasjonsalderen, slik at faren kommer inn som arving sammen med morens slekt, herunder barnets halvsøsken. ${ }^{83}$ Utvalget fant likevel ikke tilstrekkelig grunn til å fravike den ellers naturlige gjensidigheten i arveretten i slike sjelden forekommende tilfeller. I de fleste tilfeller ville faren d $\varnothing$ før barnet, og hvis barnet døde i ung alder før faren, ville barnet regelmessig etterlate seg kun ubetydelige midler. ${ }^{84}$

Blant argumenter for full likestilling var det tyngste argumentet at barn født utenfor ekteskap prinsipielt burde likestilles med barn født i ekteskap med hensyn til rettsstillingen overfor foreldrene. Videre mente utvalget at det var en verdi i seg selv at reglene var overskuelige og ukompliserte. ${ }^{85}$ Endringene i adopsjonsloven i 1956, som innførte gjensidig arverett mellom barnet og adoptivforeldrene og deres slekt, tilsa også at man burde gå samme veg med hensyn til barn født utenfor ekteskap. Utvalget konkluderte med at begrensningene i farens og farsslektens arverett etter barn født utenfor ekteskap burde oppheves. ${ }^{86}$

\subsection{Sverige}

I Sverige regulerte 1734 års lag også arveretten for barn født utenfor ekteskap. Opprinnelig hadde ikke barn født utenfor ekteskap arverett etter noen av foreldrene etter denne loven. ${ }^{87} \mathrm{I}$

\footnotetext{
${ }^{82}$ Betænkning nr. 291/1961 s. 28.

${ }^{83}$ Betænkning nr. 291/1961 s. 29.

${ }^{84}$ Betænkning nr, 291/1961 s. 29. I norsk rett har man imidlertid både i 1972-loven $\S 2$ tredje ledd andre punktum og norsk arvelov 2019 § 5 tredje ledd andre punktum funnet disse sjeldne situasjonene så viktige at man har valgt å fravike parentelprinsippet.

${ }^{85}$ Betænkning nr. 291/1961 s. 29.

${ }^{86}$ Betænkning nr. 291/1961 s. 30.

871734 års lag 8 kap. 7 §.
} 
1866 fikk barn født utenfor ekteskap en begrenset arverett etter moren, forutsatt at de ikke var et resultat av morens utroskap, eller at moren hadde fått barnet med nær beslektede eller besvogrede. ${ }^{88}$ I 1905 fikk alle barn født utenfor ekteskap full arverett etter moren og morsslekten. ${ }^{89}$

Når det gjaldt farsarv, innebar 1734 års lag at barnet fikk arverett som født innenfor ekteskap hvis foreldrene giftet seg etter at barnet født, eller dersom foreldrene var forlovet, men en av dem døde før vigselen. ${ }^{90}$ Viktigere var at også barn som var avlet under løfte om ekteskap trolovningsbarn - hadde arverett etter faren. ${ }^{91}$

I 1917 ble det gjort en begrensning i barnas arverett. ${ }^{92}$ I 1734 års lag hadde barn som var unnfanget ved voldtekt, samme arverett som barn født innenfor ekteskap. ${ }^{93}$ Arverett etter far kunne i slike tilfeller anses som en kompensasjon for farens forbrytelse. Særbestemmelsen for barn som var resultat av voldtekt, ble opphevet ved loven fra 1917 om barn født utenfor ekteskap.

Etter at Norge og Island hadde innført farsarv for barn født utenfor ekteskap, ble spørsmålet tatt opp i stor bredde i SOU 1925: $43 .{ }^{94}$ Lagberedningen $\emptyset$ nsket imidlertid ikke å følge sporet til naboene i vest:
«Samma synpunkter som leda till skyldskapsarvets begränsning, ligga ock till grund for förslagets ståndpunkt i fråga om utomäktenskapliga barns arvsrätt. Då för närvarande en på skyldskapskänsla grundad social och ekonomisk samhörighet mellan det utomäktenskapliga barnet och dess fader eller fädernefränder icke lärer genom lagstiftning kunna framtvingas, har utöver gällande lag arvsrätt dem emellan icke föreslagits, dock att arvsrätt stadgats efter fadern, då av honom avgivits förklaring, att barnet skall njuta arvsrätt efter honom såsom barn av äktenskaplig börd. I detta fall, då ovan nämnda samhörighet får anses genom viljeförklaring omedelbart fastställd, bör ock arvsrätt efter barnet tillkomma fadern.» ${ }^{95}$

Det ble likevel åpnet for at faren ved en erklæring kunne gi barnet arverett. ${ }^{96}$ Erklæringen innebar at det ble etablert arverettslige bånd mellom faren og barnet, men ikke mellom farsslekten for øvrig og barnet. Heller ikke for trolovningsbarn var det arverettslige bånd mellom barnet og farens slekt. En stor andel av barna som var født utenfor ekteskap i Sverige, hadde arverett, enten som trolovningsbarn eller etter erklæring fra faren. I statistikk som det er redegjort for i SOU 1954: 6, var $47 \%$ av barna som var født utenfor ekteskap og hvor farskapet var fastslått, trolovningsbarn. Erklæring fra faren om arverett for barna forelå i $1 \%$ av tilfellene. Totalt hadde nær halvparten av barna som farskapet var fastslått for, arverett etter faren. Barn født utenfor ekteskap kunne på visse vilkår også gjøre krav på underholdsbidrag fra boet etter arvslagen 8. kap. 9 og 10 §.

Da spørsmålet om farsarv for barn født utenfor ekteskap kom opp i forslaget til ärvdabalk i 1954, var tonen en annen:

\footnotetext{
${ }^{88}$ Förordning 14. april 1866.

${ }^{89}$ Lag 17. mars 1905. Det var imidlertid en meget kort preskripsjonsfrist for slike barns arverett (år og dag).

901734 års lag 8 kap. $1 \S$.

911734 års lag 8 kap. 2 §.

${ }^{92}$ Lag 1917:376 om barn utom äktenskap.

931734 års lag 8 kap. 6 §.

${ }^{94}$ SOU 1925: 43 s. 210-232.

${ }^{95}$ SOU 1925: 43 s. 121.

${ }^{96}$ Lag 1928: 2793 kap. 2 §.
} 
«Principiella betänkligheter mot att i arvsrättsligt hänseende helt likställa de utomäktenskapliga barnen med barn i äktenskap föreligga ej enligt de sakkunnigas mening. Visserligen anses blodsbandet icke enbart utan endast i förening med den därmed förknippade sociala och ekonomiska samhörigheten utgöra arvsrättens grund, men vid så nära släktskap som mellan fader och barn kan avgörande vikt icke tillmätas det förhållandet att vid utomäktenskaplig börd samhörigheten i allmänhet är ganska ringa.» ${ }^{97}$

Ärvdabalksakkunniga anså ikke problemene knyttet til med sikkerhet å fastslå farskapet som noen avgjørende innvending etter de fremskritt som var gjort i legevitenskapen på dette området. Det ble heller ikke ansett som noen avgjørende innvending at arverett for barn født utenfor ekteskap ville gripe inn i arveretten for både barna som var født innenfor ekteskap, og for ektefellens rettsstilling. For ektefellens del ville den fortrinnsrett til midlene i små dødsbo som ektefellen hadde krav på, sikre ektefellen et visst minimum selv om avdøde etterlot seg særkullsbarn. De arverettslige båndene burde være av samme karakter som for barn født i ekteskap, slik at det skulle være gjensidig arverett ikke bare mellom far og barn, men også mellom farsslekten og barnet. $^{98}$

Selv om Ärvdabalksakkunniga ønsket å likestille barn født henholdsvis innenfor og utenfor ekteskap, mente de at de nye reglene bare skulle gjelde for barn født etter lovendringens ikrafttreden. For trolovningsbarn og barn som faren allerede hadde avgitt erklæring om arverett for, kunne reglene også få tilbakevirkende kraft. ${ }^{99}$ Usikkerhet omkring det faktiske grunnlaget bak eldre fastsettelser av farskap og utilstrekkelige opplysninger i folkeregistreringen ble fremhevet som hensyn mot å gi de nye reglene tilbakevirkende kraft. $^{100}$

Justitierådet Gösta Walin avga en dissenterende særmerknad med hensyn til spørsmålet om reglene skulle gis tilbakevirkende kraft. ${ }^{101}$ Han mente at man også i spørsmålet om arverett for barn født utenfor ekteskap burde følge den sedvanlige regelen for skjæringstidspunktet mellom eldre og nyere arverettslige bestemmelser - nemlig arvelaterens død. Etter Walins syn var likestillingen mellom barn født innenfor og utenfor ekteskap på ingen måte noen revolusjonær nyvinning som var i forkant av rettsutviklingen:

«Likställigheten i arvshänseende mellan inom- och utomäktenskapliga barn är snarare en efterbliven bekräftelse på en redan skedd social omvärdering, och undantaget för redan födda barn kommer att med skärpa understryka deras hittillsvarande principiellt ohållbara särställning.» ${ }^{102}$

Walin foreslo overgangsregler som i større grad ville gi arverett også for barn født før den nye lovens ikrafttreden. Hvis arveretten ikke var avklart mens faren fortsatt var i live, måtte barnet gjøre sitt arvekrav gjeldende overfor dødsboet innen ett år fra dødsfallet. ${ }^{103}$

De fleste høringsinstansene støttet forslaget om utvidet arverett for barn født utenfor ekteskap. Noen høringsinstanser mente likevel at sikrere måter for fastsettelse av farskap var en forutsetning for å likestille barn født i og utenfor ekteskap. Andre høringsinstanser mente at ektefellens arverettslige stilling måtte styrkes før likestillingen kunne skje. Noen

\footnotetext{
${ }^{97}$ SOU 1954: 6 s. 73-74.

${ }^{98}$ SOU 1954: 6 s. 74.

${ }^{99}$ SOU 1954: 6 s. 74-75.

${ }^{100}$ SOU 1954: 6 s. 127-131.

101 SOU 1954: 6 s. 217-226.

102 SOU 1954: 6 s. 118 (uthevet av Walin).

${ }^{103}$ SOU 1954: 6 s. 232.
} 
høringsinstanser motsatte seg likestilling på prinsipielt grunnlag: Den sosiale og økonomiske samhørigheten som mellom arvelater og arving manglet. ${ }^{104}$

De fleste høringsinstanser støttet i prinsippet Walins overgangsregler, men flertallets overgangsregler var mindre kompliserte, noe som var avgjørende for at mange likevel gikk inn for løsningen uten tilbakevirkende kraft. ${ }^{105}$

Justisministeren fremhevet i sin uttalelse til Lagrådet at store befolkningsgrupper så reformen som uunngåelig ut fra et rettferdighetssynspunkt. ${ }^{106}$ Manglende sosial og $\varnothing$ konomisk samhørighet var ingen avgjørende innvending mot arverett for så nære slektninger som arvelaterens barn. Arveretten var dessuten ment å styrke samhørigheten mellom faren og barnet. Når det gjaldt de bevismessige utfordringene med å fastslå farskapet med sikkerhet, ble det vist til at denne usikkerheten i prinsippet var like stor for barn født innenfor ekteskap, selv om den der sjelden ble satt på spissen på grunn av pater est-regelen. Justisministeren hadde sympati for Walins forslag om å gi de nye reglene tilbakevirkende kraft for barn født før lovens ikrafttreden, men gikk likevel inn for flertallets forslag.

Til tross for at både Ärvdabalksakkunniga og justisministeren gikk inn for lik arverett for barn født henholdsvis innenfor og utenfor ekteskap, gikk Lagrådet sterkt imot forslaget. Lagrådet vektla særlig at den sosiale og økonomiske tilknytningen mellom barnet og faren manglet, og usikkerheten med å fastslå farskapet. Lagrådet trakk også frem gjenlevende ektefelles stilling. Lagrådet mente man kunne overveie å innføre arverett for barn født utenfor ekteskap i tilfeller hvor faren hadde erkjent farskapet, og i saker hvor det forelå dom for farskapet og domstolen ikke hadde funnet spørsmålet tvilsomt. ${ }^{107}$

Justisministeren delte ikke Lagrådets prinsipielle oppfatning av spørsmålet om arverett for barn født utenfor ekteskap. Imidlertid mente han at utvidelsen av arveretten for barn født utenfor ekteskap burde utsettes til nye regler for beskyttelse av gjenlevende ektefelle var på plass. $^{108}$

Familierettskomiteen foreslo endringer i gjenlevende ektefelles rettsstilling. På bakgrunn av disse endringene så komiteen ingen grunn til å beholde særlige regler om arverett for barn født utenfor ekteskap. Komiteen gikk inn for en likestilling med barn født innenfor ekteskap. I spørsmålet om overgangsregler fulgte komiteen flertallet fra Ärvdabalksakkunniga. ${ }^{109}$

I Prop. 1969: 124 tok justisministeren igjen til orde for å likestille barn født utenfor ekteskap med barn født innenfor ekteskap. Et av ankepunktene mot å likestille barn født utenfor ekteskap med barn født innenfor ekteskap hadde vært hensynet til gjenlevende ektefelle. Familjerättskommittéen hadde foreslått en rekke endringer som i vesentlig grad styrket gjenlevende ektefelles stilling i skifteoppgjøret etter førstavdøde ektefelles død. Disse forslagene var blitt utsatt for hard kritikk i høringsrunden. Regjeringen hadde på bakgrunn av dette i Prop. 1968: 136 foreslått en grunnleggende revisjon av ekteskapslovgivningen. Etter justisministerens syn kunne ikke spørsmålet om arverett for barn født utenfor ekteskap utsettes enda en gang i påvente av nye utredninger. Han anførte at sammenkoplingen mellom

\footnotetext{
104 Proposition nr. $124 / 1969$ s. 62.

105 Proposition nr. 124/1969 s. 62-63.

106 Proposition nr. 144/1958 s. 96-103.

107 Proposition nr. 144/1958 s. 321-329.

108 Prop. 1958: 144 s. 350-351.

${ }^{109}$ Prop. 1969: 124 s. 67.
} 
arverett for barn født utenfor ekteskap og gjenlevende ektefelles stilling var blitt overbetont i den tidligere diskusjonen:

«Att skydda efterlevande makens hem kan vara like angeläget vare sig det barn som skulle kunna splittra hemmet genom att ta ut sin arvslott är den avlidne makens barn utom äktenskap eller hans barn $\mathrm{i}$ tidigare äktenskap eller rentav makarnas gemensamma barn.» ${ }^{110}$

Justisministeren trakk frem at for gjenlevende ektefelle var både reglene om deling av felleseiet og pensjonsreglene viktigere for den økonomiske situasjonen enn arvereglene. ${ }^{111} \mathrm{Et}$ grep som ble foreslått, og også fulgt opp av lovgiver, var å øke det beløpet som en ektefelle hadde rett til å sitte igjen med. ${ }^{112}$ Justisministeren redegjorde også for ulike forslag til endringer relatert til prosessen i farskapssaker. ${ }^{113}$ Etter justisministerens syn måtte arveretten for barn født utenfor ekteskap være fullt ut likestilt med arveretten for barn født innenfor ekteskap. Dette innebar at det måtte være arverett ikke bare etter faren, men også etter farsslekten for $\varnothing v$ rig. ${ }^{114}$ Justisministeren mente at det heller ikke var grunn til å utelukke faren og farsslekten fra arverett i de tilfeller hvor barnet var unnfanget ved farens voldtekt av moren. ${ }^{115}$

Når det gjaldt overgangsregler, la justisministeren til grunn at den nye loven burde settes i kraft 1. januar 1970, og at skjæringstidspunktet for når de nye arvereglene skulle gjelde, burde ta utgangspunkt i om arvelateren døde før eller etter at loven ble satt i kraft. Justisministeren mente at å knytte skjæringstidspunktet til om barnet var født før eller etter lovens ikrafttreden, ville gi de gamle reglene virking til langt ut på 2000-tallet og «konservera vad som numera allmänt erkänns vara en social orättvisa». ${ }^{116}$ Han syntes ikke det var grunn til å legge vekt på muligheten for at farskap som var fastsatt etter eldre rett, kunne være fastsatt på feilaktig grunnlag, i vurderingen av hvilke barn som skulle ta arv etter de nye arvereglene.

Et praktisk problem ved implementeringen av de nye reglene var at folkeregistreringen i kirkebøkene i begrenset grad opplyste om barn født utenfor ekteskap. Først fra 1. januar 1968 skulle alle barn registreres på en persons folio i registeret, men registreringsplikten hadde ikke tilbakevirkende kraft. Barn født utenfor ekteskap kunne derfor bli forbigått i arveoppgjøret. Dette gjaldt særlig barn født før 1950. Barnet selv burde derfor gis rett til å bli skrevet inn i farens akt i folkeregisteret. Uavhengig av hva som var registrert på avdøde, burde barnet sikres arverett hvis noen av de $\varnothing$ vrige arvingene, boutredningsmannen eller den som satt med boet, hadde fått kunnskap om barnet før bouppteckningen (registrering av avdødes eiendom og gjeld). Det ble imidlertid satt en særskilt preskripsjonsfrist. Barnet arvet bare hvis boutredningsmannen, andre arvinger eller den som satt med boet, senest ved bouppteckningen hadde fått kunnskap om barnet, eller at registrering av barnet var gjort i personakten til arvelateren eller en annen arving som barnet utledet sin arverett fra, før arvefallet. De alminnelige foreldelsesreglene for arverett skulle ikke få anvendelse i slike tilfeller. ${ }^{117}$

\footnotetext{
${ }^{110}$ Prop. 1969: 124 s. 75.

${ }^{111}$ Prop. 1969: 124 s. 75.

112 Prop. 1969: 124 s. 77-78.

113 Prop. 169: 124 s. 79-89.

114 Prop. 1969: 124 s. 90.

115 Prop. 1969: 124 s. 90.

116 Prop. 1969: 124 s. 91.

117 Prop. 1969: 124 s. 93.
} 
Riksdagen vedtok likestillingen av barn født utenfor ekteskap med hensyn til arverett etter faren og farsslekten. ${ }^{118}$ Det tok likevel ikke lang tid før man kom til at de særlige preskripsjonsfristene for å gjøre gjeldende arvekrav for barn født utenfor ekteskap var problematiske. Bouppteckning ble noen ganger foretatt umiddelbart etter dødsfallet, mens det andre ganger kunne trekke ut i tid før den ble gjort. Preskripsjonstidspunktet kunne derfor bli usikkert å beregne for arvingen. ${ }^{119}$ Noen ganger var bouppteckningen foretatt umiddelbart etter dødsfallet fordi det var mistanke om at det kunne dukke opp barn født utenfor ekteskap. ${ }^{120}$ Arveretten kunne være preskribert før barnet var blitt klar over dødsfallet og derved fått mulighet til å gi seg til kjenne. Det ble foreslått en endring slik at barnet fikk en viss tid på seg for å fremme sitt arvekrav. ${ }^{121}$ Fristen ble satt til tre måneder fra dødsfallet. Fristen sammenfalt med fristen for å foreta bouppteckning i ärvdabalken 20. kap. $1 \S$. Hvis bouppteckningen ble gjort senere enn tre måneder etter dødsfallet, løp fristen likevel ikke ut før ved bouppteckningen. ${ }^{122}$

\subsection{Finland}

Om Sverige var sent ute med å likestille barn født innenfor og utenfor ekteskap, var naboene på den andre siden av Bottenviken enda senere ute. Først i 1975 ble det gjort endringer i ärvdabalken som likestilte barn født innenfor og utenfor ekteskap. Endringene trådte i kraft 1. oktober 1976.

Hvis arvelateren døde før de nye reglenes ikrafttreden, var utgangspunktet at barn født utenfor ekteskap ikke hadde arverett etter faren og farsslekten. Det var imidlertid som i eldre svensk rett slik at trolovningsbarn hadde samme arverett som barn som var født innenfor ekteskap, jf. ärvdabalken 2. kap. 4. §. Faren kunne også erkjenne barnet som sitte eget, med den virkning at barnet fikk samme arverettslige stilling som om det var født innenfor ekteskap, jf. lag om barn utom äktenskap $§ \S 20$ og 21. ${ }^{123}$ Ved erkjennelsen ble det bare etablert arverettslige bånd mellom faren og barnet, ikke mellom barnet og farsslekten for $\varnothing v$ vig.

Hvis barnet allerede under de reglene som gjaldt forut for 1. oktober 1976, hadde arverett etter faren - noe som var tilfellet for trolovningsbarn og barn hvor faren hadde erkjent farskapet gjaldt det som var fastsatt $i$ eldre rett om arverett etter faren og farsslekten. Hvis avdøde etter eldre rett var pålagt underholdsbidrag til barnet, men ikke hadde erkjent farskap, innebar overgangsreglene at barnet ville ha rett til bidrag etter bestemmelsene i ärvdabalken kap. 8 om bidrag til arvelaterens barn.

\section{Legalarveretten for barn som er adoptert}

\subsection{Innledning}

Barn som er adoptert, har ikke - som barn født utenfor ekteskap - vært utelukket fra arverett. Ved adopsjon har spørsmålet vært hvilken slekt barnet skal arve, og hvilken slekt som skal arve barnet. Her har det vært to ulike modeller: svake og sterke adopsjoner. Ved svak adopsjon består de arverettslige båndene til den biologiske slekten, og barnet får ikke arverett etter adoptivforeldrene og deres slekt. Ved sterk adopsjon brytes de arverettslige båndene til den biologiske slekten, men barnet arver og blir arvet av adoptivforeldrenes slekt som om det

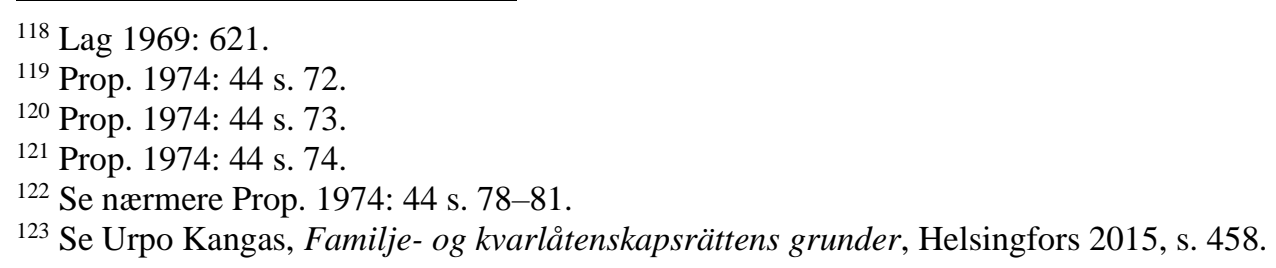


skulle være adoptivforeldrenes biologiske barn. Det er også mellomformer mellom svak og sterk adopsjon. Utviklingen i Norden i de siste 100 årene har gått fra svak til sterk adopsjon.

\subsection{Den første bølgen av nordisk adopsjonslovsamarbeid}

Samarbeidet mellom de nordiske landene som blant annet førte frem til den fellesnordiske ekteskapslovgivningen, omfattet også samarbeid om felles adopsjonslover. På dette tidspunktet var det kun i Danmark at adopsjonsinstituttet var i aktiv bruk. I Danmark hadde det $\mathrm{i}$ lang tid vært en utbredt praksis med adopsjon gjennom administrative bevillinger, mens det i de øvrige nordiske landene enten aldri hadde vært særlig i bruk, eller det var gått ut av bruk. ${ }^{124}$ I Norge lå den siste kjente adopsjonsbevillingen så langt tilbake som $1845 .{ }^{125}$

Det nordiske lovsamarbeidet førte frem til adopsjonslover i Norge og Sverige i 1917, i Danmark i 1923, og i Finland i 1925. ${ }^{126}$ Lovene bygde i store trekk på den praksis som hadde utviklet seg i Danmark på adopsjonsrettens område. I arverettslig henseende gikk ordningen ut på at barnet som ble adoptert, og barnets livsarvinger ble arvinger etter adoptivforeldrene. Det ble derimot ikke knyttet arverettslige bånd mellom barnet og adoptivforeldrenes slekt. På den andre siden beholdt barnet arverett etter sin biologiske slekt. Det var også kun den biologiske slekten som etter lovens hovedregel arvet barnet. Adopsjon ble sett på som et rettsforhold kun mellom barnet og adoptivforeldrene. ${ }^{127}$

Som illustrasjon på de fellesnordiske adopsjonslovene kan den danske adopsjonsloven av 1923 tjene til illustrasjon. Frem til 1923 var utgangspunktet for danske adopsjoner at adopsjonen var svak, og at barnet beholdt de arverettslige båndene til de biologiske foreldrene og deres slekt. Det kunne likevel fastsettes bestemmelser om arverett etter adoptivforeldrene i adopsjonsbevillingen. Den danske adopsjonsloven av 1923 bygget på en mellomform mellom svak og sterk adopsjon. Adopsjonen knyttet arverettslige bånd mellom barnet og adoptivforeldrene, men ikke mellom barnet og adoptivforeldrenes slekter. Dessuten bestod de arverettslige båndene mellom barnet og den biologiske slekten. I hvilken grad barnets arverett etter adoptivforeldrene var beskyttet mot testamentariske disposisjoner, avhang av om det $\mathrm{i}$ adopsjonsbevillingen var tatt forbehold om innskrenkninger i adoptantens testasjonsrett. Hvis det var tatt testasjonsforbehold, ble barnet legalarving etter adoptivforeldrene, som andre barn, men var ikke beskyttet av pliktdelsreglene. Hvis det derimot ikke var tatt testasjonsforbehold, var barnet også beskyttet mot adoptivforeldrenes testamentariske disposisjoner. Barnet hadde ikke arverett etter adoptivforeldrenes slekt. Adoptivforeldrene hadde dessuten bare unntaksvis arverett etter barnet. Det første unntaket var hvis barnet ikke etterlot seg arveberettigede biologiske slektninger eller ektefelle. Det andre unntaket var dersom et barn som var adoptert, hadde arvet en av adoptivforeldrene, men så døde uten å etterlate seg livsarvinger. I et slikt tilfelle skulle arven fra den førstavdøde av adoptivforeldrene falle tilbake til den gjenlevende av adoptivforeldrene fremfor å gå til barnets biologiske slekt.

\footnotetext{
${ }^{124}$ Jørgen Trolle, «Skandinavisk omstøbning av adotopnsinstituttet», TfR 1956, s. 1.

${ }^{125}$ Utkast til lov om arv 1962, s. 21.

${ }^{126}$ Lov 2. april 1917 (Norge); lag 14. juni 1917 (Sverige); lov 26. mars 1923 (Danmark); lag 5. juni 1925 (Finland).

${ }^{127}$ Jørgen Trolle, «Skandinavisk omstøbning av adoptionsinstituttet», TfR 1956, s. 1.
} 
I Danmark ble adopsjon brukt i tre ulike situasjoner. Det vanligste var anonyme adopsjoner. ${ }^{128}$ I slike tilfeller adopterte barnløse par spedbarn som foreldrene ikke var i stand til å ta vare på. Barna var ofte født av en ugift mor. Ved anonyme adopsjoner kjente ikke adoptivforeldrene barnet eller foreldrene fra før. Det var heller ikke vanlig at kontakten mellom barnet og den biologiske slekten ble opprettholdt. En annen utbredt form for adopsjon var stebarnsadopsjon, hvor den ene ektefellen adopterte den andre ektefellens barn. Ofte var dette barn som kvinnen hadde fått utenfor ekteskapet, og som mannen adopterte etter at de giftet seg, men det kunne også være barn fra et tidligere ekteskap som var oppløst ved skilsmisse eller død. ${ }^{129}$ Den tredje varianten av adopsjoner var familieadopsjoner, hvor barn som hadde mistet sine foreldre, ble adoptert av familiemedlemmer, som besteforeldre eller onkler og tanter, eller i mer sjeldne tilfeller nære venner av foreldrene. ${ }^{130}$

Sverige fikk som nevnt sin første adopsjonslov i 1917. Som de øvrige nordiske adopsjonslovene fra denne tiden bygde den svenske loven på svak adopsjon. De arverettslige båndene til den biologiske slekten ble opprettholdt, og barnet hadde bare i begrenset grad arverett etter adoptivforeldrene sammenlignet med biologiske barn. I 1928 ble regler om arverett i adopsjonsforhold regulert i arvslagen 4. kap. Om grunnlaget for arverett i adopsjonsforhold ble det i forarbeidene uttrykt følgende: «Adoptionen skapar i viss omfattning den ekonomiska och sociala samhörighet, som är grundläggande för arvsrätten.» ${ }^{131}$ Barnet fikk ved adopsjon arverett som barn født innenfor ekteskap, men med det forbehold at adoptivforeldrenes biologiske barn ikke som følge av adopsjonen skulle få begrenset sin rett til pliktdelsarv (laglott). I utgangspunktet beholdt barnet arverett etter den biologiske slekten, og den biologiske slekten beholdt arverett etter barnet. Hvis barnet hadde mottatt arv eller gave fra adoptivforeldrene, kunne adoptivforeldrene og deres etterkommere komme inn som arvinger for verdier tilsvarende arven eller gaven som barnet hadde mottatt fra adoptivforeldrene. Hvis barnet døde uten arveberettigede biologiske slektninger, kunne dessuten adoptivforeldrene tre inn som arvinger.

Etter den norske adopsjonsloven av 1917 hadde adopterte barn i utgangspunktet arverett som adoptivforeldrenes egnefødte barn, men dersom det både var biologiske barn og barn som var adoptert, kunne ikke arven som skulle gå til de adopterte barna, gripe inn i pliktdelsarven til de biologiske barna. ${ }^{132}$ Det var også større adgang til å testamentere på bekostning av adopterte barn enn det man kunne gjøre på bekostning av egnefødte barn, da de adopterte barnas pliktdelsarv utgjorde halvparten av deres arvelodd, jf. adopsjonsloven $\S 14$. Adoptivforeldrene hadde arverett etter barnet dersom barnet ikke etterlot seg ektefelle eller arveberettigede biologiske slektninger, jf. adopsjonsloven $\S 15$.

\subsection{Norge tar et skritt $i$ retning av sterke adopsjoner i 1935}

Norge var først ute med å ta steget over mot de sterke adopsjonene. Ved en endring av adopsjonsloven i 1935 åpnet man for sterke adopsjoner hvor det arverettslige båndet mellom barnet og den biologiske slekten ble brutt, samtidig som fullstendige arverettslige bånd til

\footnotetext{
${ }^{128}$ I Danmark utgjorde slike adopsjoner ca. $60 \%$ av alle adopsjoner på 1950-tallet. Jørgen Trolle, «Skandinavisk omstøbning av adoptionsinstituttet, TfR 1956, s. 3.

${ }^{129}$ I Danmark utgjorde slike adopsjoner ca. $25 \%$ av adopsjonene, jf. Trolle, op.cit., s. 4.

${ }^{130}$ I Danmark utgjorde slike adopsjoner på 1950-tallet ca. $12 \%$ av adopsjonene, jf. Trolle, op.cit., s. 5.

${ }^{131}$ SOU 1925: 43 s. 121.

132 Se nærmere Ot.prp. nr. 66 (1916) s. 9-10.
} 
adoptivforeldrene og deres slekt ble etablert. ${ }^{133}$ Barnet ville således både arve og bli arvet av adoptivforeldrene og deres slekt.

Adopsjonslovens regler om arverett hadde gjennom flere år vært utsatt for kritikk. Kritikken gikk dels på at barnets arverett var svak sammenlignet med arveretten for adoptivforeldrenes biologiske barn, og dels på at adoptivforeldrene som utgangspunkt ikke hadde arverett etter barnet. ${ }^{134}$ Det ble påpekt som en svakhet ved den norske loven at den ikke hadde en regel om tilbakefall av arv og gaver fra adoptivforeldrene, slik man hadde det i både dansk og svensk rett. ${ }^{135}$ Dette ble det foreslått å endre i Ot.prp. nr. 25 (1934). Forslagene ble satt på vent, da det ble avgitt en ny proposisjon året etter - Ot.prp. nr. 30 (1935). Proposisjonen fra 1935 var foranlediget av en artikkel i Aftenposten i 1934 av høyesterettsadvokat Leif S. Rode, som kritiserte både den gjeldende adopsjonslovgivning og forslagene fra 1934. Rode mente det var uholdbart at barnet i arverettslig henseende ble «svevende mellom to slekter». ${ }^{136}$

Departementet gikk inn for en ordning som åpnet for «fullstendig familievalg», hvor man ble fullt ut integrert i adoptivforeldrenes slekt samtidig som båndene til den biologiske slekten ble brutt:
«I de tilfelle $[\ldots]$ hvor barnet vokser op i den tro at det er adoptivforeldrenes virkelige barn, samtidig med at dets virkelige foreldre har fraskrevet sig enhver rett til å ha forbindelse med barnet eller endog retten til å vite hvor det er, og av hvem det er adoptert, der synes billighet å tale for at der åpnes adgang til å etablere i arverettslig henseende et gjensidig forhold mellom adoptivforeldrene og deres livsarvinger på den ene side og adoptivbarnet på den annen side som om adoptivbarnet var adoptivforeldrenes eget. Efter departementets mening vil det endog i disse tilfelle være naturlig at der etableres arverettslig forhold også mellom adoptivbarnet og adoptivforeldrenes fjernere slektninger, som barnet vil betrakte som sine slektninger, og som vel også selv oftest vil likestille barnet med en slektning.» ${ }^{137}$

En sterk adopsjon kunne etableres enten i forbindelse med den opprinnelige adopsjonsbevillingen eller på et senere tidspunkt, jf. adopsjonsloven $\S 15$ b. Denne formen for adopsjon ble raskt den mest brukte i Norge. Av adopsjonsbevillingene som ble gitt på midten av 1950-tallet, ble arveretten utvidet til sterk adopsjon i $98 \%$ av tilfellene. ${ }^{138}$ En annen endring som kom inn ved lovendringen i 1935, var at adoptivforeldrene ved testament skulle kunne fastsette lik arverett som for egnefødte barn. En slik testamentarisk bestemmelse krevde imidlertid kongelig stadfestelse. Det ble også gjort andre endringer som innebar noe sterkere arverettslige bånd mellom barnet og adoptivforeldrene og deres slekt, også ved svake adopsjoner. ${ }^{139}$

\subsection{En svipptur til Island}

Da arbeidet med de fellesnordiske adopsjonslovene pågikk i rundt første verdenskrig, hadde Island ennå ikke løsrevet seg fra Danmark. Island fikk sin første adopsjonslov i $1953 .{ }^{140}$ I den islandske arveloven av 1949 ble det bestemt at barn som var adoptert, hadde arverett som

\footnotetext{
${ }^{133}$ Lov 24. mai 1935 nr. 2.

${ }^{134}$ Ot.prp. nr. 25 (1934) s. 3.

135 Ot.prp. nr. 25 (1934) s. 4.

${ }^{136}$ Ot.prp. nr. 30 (1935) s. 6.

137 Ot.prp. nr. 30 (1935) s. 8.

138 Ot.prp. nr. 26 (1956) s. 3.

${ }^{139}$ Se redegjørelsen i Utkast til lov om endringer i lov om adopsjon av 2. april 1917, på s. 6.

${ }^{140}$ Lov nr. 19, 11. februar 1953 (adopsjonsloven).
} 
adoptantenes egne barn. Arveretten var beskyttet som pliktdelsarv, og det var ingen hjemmel for å gjøre unntak i adopsjonsbevillingen. ${ }^{141}$

Den formen for adopsjon som ble innført på Island i 1953, må likevel klassifiseres som en svak adopsjon. Barnet beholdt arverett etter sine biologiske slektninger, og de biologiske slektningene var også arvinger etter barnet. Adoptivforeldrene og deres slekt hadde bare arverett i to situasjoner: 1) Hvis barnet døde uten livsarvinger (herunder adoptivbarn), ville adoptivforeldrene og deres barn, men ikke fjernere livsarvinger, arve barnet i den grad barnet hadde arvet eller mottatt gaver fra adoptivforeldrene. 2) Hvis barnet verken etterlot seg arveberettigede biologiske slektninger, adoptivbarn eller ektefelle, og barnet heller ikke hadde rådet over sin formue ved testament, ville adoptivforeldrene og adoptivforeldrenes barn, men ikke fjernere livsarvinger eller utarvinger etter adoptivforeldrene, arve. ${ }^{142}$

\subsection{Den andre bølgen av nordisk adopsjonslovsamarbeid}

På slutten av 1940-tallet kom adopsjon igjen inn på agendaen i de nordiske forhandlingene om fellesnordisk familierettslovgivning. Det ble avgitt betenkninger i 1954, som blant annet foreslo nye arverettslige regler ved adopsjon. ${ }^{143}$ Det var særlig erfaringene med den norske lovendringen i 1935 som lå til grunn for forslagene fra de nordiske kommisjonene.

Kommisjonene foreslo et tosporet system for adopsjoner. Hovedregelen skulle være sterke adopsjoner som i den norske loven av $1935 .{ }^{144}$ Som alternativ kunne man ha en form for svak adopsjon, men den svake adopsjonen etter disse forslagene var langt fra så svak som de tradisjonelle svake adopsjonene. Barnet skulle nemlig være arveberettiget etter både adoptivforeldrene og deres slekt, men bevare arverett etter den biologiske slekten. Når det gjaldt arverett etter barnet, skulle den biologiske slekten som hovedregel være arving, men med en ganske subsidiær arverett for adoptivforeldrene og deres slekt. ${ }^{145}$

På et nordisk ministermøte i København i 1955 ble justisministrene enige om at man helt skulle avskaffe de svake adopsjonene. ${ }^{146}$ I departementets proposisjon til den norske adopsjonsloven av 1956 ble det tydelig tatt til orde for å avskaffe de svake adopsjonene:

\footnotetext{
«Det kan heller ikke være tvil om - etter rettsoppfatningen i vårt land - at sterke adopsjoner prinsipielt er å foretrekke for adopsjon med svak virkning, fordi den legger forholdene bedre til rette for at barnet vil bli akseptert i sin nye familie og på sin side få samme tilknytning til denne som det hadde vært adoptantens virkelige barn. En ordning som kan gi barnet en følelse av å tilhøre to familier på en gang, kan lett virke i strid med adopsjonens formål. Muligheten av å oppnå arv fra to forskjellige hold kan bli av tvilsom verdi for barnet.
}

De grunner som kan anføres til fordel for svak adopsjon, knytter seg i virkeligheten til to helt særegne skjønt ikke upraktiske - situasjoner. Den ene er at en mann eller kvinne ønsker å adoptere sin ektefelles barn av tidligere ekteskap. Det kan da i visse tilfelle virke urimelig å stille barnet rettslig utenfor sin virkelige slekt. Her har hensynet til arveretten betydelig vekt, særlig hvis den virkelige slekt er formuende. På den annen side vil det i slike tilfeller ofte være et ønske fra alle sider at barnet opprettholder forbindelsen med sin virkelige slekt og føler seg som en del av denne. Tilsvarende hensyn

\footnotetext{
${ }^{141}$ Armann Snævarr, «Hovedpunktene i den islandske arvelovgivning», TfR 1956, s. 329-330.

142 Armann Snævarr, «Hovedpunktene i den islandske arvelovgivning», TfR 1956, s. 331.

${ }^{143}$ Den norske betenkningen er lagt ved som vedlegg til Ot.prp. nr. 26 (1956).

${ }^{144}$ Utkast til lov om endringer i lov om adopsjon av 2. april 1917 s. 7 og s. 11-13.

${ }^{145}$ Se nærmere Jørgen Trolle, «Skandinavisk omstøbning av adoptionsinstituttet, TfR 1956, s. 1 flg., med til dels sterk kritikk av den foreslåtte ordningen og de utslag den kunne gi.

${ }^{146}$ Ot.prp. nr. 26 (1956) s. 6.
} 
kan gjøre seg gjeldende når noen tar til seg et (kanskje foreldreløst) barn av en nær slektning. Det vil ofte ligge helt utenfor formålet å gripe inn i det arverettslige forhold til den virkelige slekt.

Men det mest påtrengende spørsmål i disse tilfelle er etter departementets mening ikke om adopsjonen bør være sterk eller svak, men om adopsjonen i det hele tatt bør finne sted. Når formålet bare eller hovedsakelig er å gi barnet et nytt hjem, ikke å plante det om fra en slekt til en annen, da er adopsjon ikke den mest naturlige utvei. Gjennom et alminnelig fosterbarnforhold vil barnet vanligvis kunne få den stilling man ønsker å gi det.» ${ }^{147}$

Ordningen med sterke adopsjoner passet, som sitatet ovenfor viser, godt for spedbarnsadopsjonene, men mindre godt for stebarnsadopsjoner og familieadopsjoner. I Danmark var det ganske mange av både stebarnsadopsjoner og familieadopsjoner. ${ }^{148}$ Mens Sverige og Norge gikk inn for en ubetinget ordning med sterke adopsjoner, beholdt derfor Danmark en mulighet for svake adopsjoner.

I den danske adopsjonsloven av 1956, ${ }^{149}$ som bygde på anbefalingene fra de fellesnordiske forhandlingene, var hovedregelen sterk adopsjon. Ifølge lovens $§ 13$ skulle det være gjensidig arverett mellom på den ene siden det adopterte barnet og barnets livsarvinger og på den andre siden adoptivforeldrene og adoptivforeldrenes slekt. De arverettslige båndene til barnets biologiske slekt skulle samtidig brytes. Det var imidlertid en åpning for at man i adopsjonsbevillingen kunne bestemme at barnets arverett etter den biologiske slekten skulle bestå. Ved stebarnsadopsjon skulle barnet stilles arverettslig som ektefellenes fellesbarn, jf. lovens $\S 15$. Det ville således knyttes arverettslige bånd mellom den adopterende steforelderen og barnet samtidig som de arverettslige båndene til den biologiske forelderen som steforelderen var gift med, ville bestå. Reglene i 1956-loven gjaldt for adopsjonsbevillinger utstedt etter 1. januar 1957. I forbindelse med 1956-loven ble det åpnet for at Justisdepartementet etter søknad kunne konvertere eldre, svake adopsjoner til sterke adopsjoner. ${ }^{150}$

\subsection{Senere endringer}

I den danske arveloven av 1963 ble det presisert i $\S 4$ at barn som var adoptert, var omfattet av lovens uttrykk «livsarvinger» og «børn», og at «slægtninge», «forældre» og «bedsteforældre» omfatter slektskap som følge av et adoptivforhold.

Den danske adopsjonsloven av 1972 opprettholdt systemet med sterk adopsjon. ${ }^{151}$ Ved loven av 1972 opphørte muligheten til å ta forbehold om å bevare arverett etter den biologiske slekten, i tillegg til arverett etter adoptivforeldrene og deres slekt. ${ }^{152}$ Ved stebarnsadopsjon bortfalt imidlertid bare arveretten etter den av foreldrene som ikke var eller hadde vært gift med adoptanten, og dennes slekt. ${ }^{153}$ Barnet fikk således samme arverettslige stilling som om det var fellesbarn av adoptanten og barnets biologiske mor eller far som var gift med adoptanten. På samme måte som adopsjonsloven av 1956 ga adopsjonsloven av 1972 adgang

\footnotetext{
${ }^{147}$ Ot.prp. nr. 26 (1956) s. 6-7 (uthevet i proposisjonen).

148 Jørgen Trolle, «Skandinavisk omstøbning av adoptionsinstituttet, TfR 1956, s. 5 flg.

${ }^{149}$ Lov nr. 2. 140 af 25 maj 1956 om adoption.

${ }^{150}$ Se lovens $§ 27$ stk. 2.

${ }^{151}$ Lbkg. Nr. 1041 af 3. august 2018. Lovens $§ 16$ stk. 1.

${ }^{152}$ Irene Nørgaard, Caroline Adolphsen og Eva Naur, Arveret, 7. udg., København 2018, s. 43-44.

$153 \S 16$ stk. 2.
} 
til å endre en eldre, svak adopsjon til en sterk adopsjon. ${ }^{154}$ Den nye danske adopsjonsloven av 2018 viderefører i $§ 16$ de arverettslige rettsvirkningene av adopsjon fra 1972-loven.

I forbindelse med vedtakelsen av den svenske ärvdabalken i 1958 ble det gjort vesentlige endringer med hensyn til arverett i adopsjonsforhold på bakgrunn av de overlegningene som var gjort i de nordiske ministermøtene. Adopsjoner som ble gjennomført etter at loven ble satt i kraft 1. juli 1959, skulle være sterke adopsjoner. Barnet skulle ta arv som om det var adoptivforeldrenes barn født innenfor ekteskap, jf. ärvdabalken 4. kap. $1 \S$. Adopsjoner som var gjennomført før 1. juli 1959, kunne endres til sterk adopsjon gjennom såkalt «omadoption» hvis dette ble gjort innen 1. juli 1964.

I 1970 ble de gjenværende svake adopsjonene endret med tilbakevirkende kraft. Med virkning fra 1. juli 1971 ble alle adopsjoner i Sverige - uansett adopsjonstidspunkt - endret til sterke adopsjoner.

Sverige har i dag ingen egen lov om adopsjon. Reglene om adopsjon har siden 1949 vært inntatt i kapittel 4 i föräldrabalken. De særlige reglene om adopsjon i ärvdabalken ble opphevet i 1971. ${ }^{155}$ Bestemmelsen om rettsvirkningene av adopsjon i föräldrabalken er etter en lovendring i 2018 inntatt i 4 kap. 21 §:

\begin{abstract}
«Den som har adopterats ska anses som adoptivförälderns barn och inte som barn till sina tidigare föräldrar. Om en make eller sambo har adopterat den andra makens eller sambons barn, ska den som har adopterats dock anses som makarnas eller sambornas gemensamma barn. Lag eller annan författning som tillägger släktskapet mellan barn och förälder rättslig betydelse ska tillämpas på den som har adopterats och hans eller hennes adoptivförälder.
\end{abstract}

Första stycket gäller inte i den utsträckning något annat är särskilt föreskrivet eller följer av rättsförhållandets natur.»

Finland var sent ute med å gå over til sterke adopsjoner. Den finske adopsjonsloven av 1925 var i store trekk bygget over samme lest som de tilsvarende lovene i Sverige, Danmark og Norge. De gamle reglene om svak adopsjon innebar at barnet etter adopsjonen ble betraktet som livsarving etter sine biologiske foreldre. De biologiske foreldrene ble ansett som arvinger etter barnet dersom barnet ikke etterlot seg egne livsarvinger. ${ }^{156}$ Finland holdt lenge på muligheten for svake adopsjoner. Både adopsjonsloven av 1979 og adopsjonsloven av 1985 holdt denne muligheten åpen, selv om hovedregelen i disse lovene var at adopsjonen var sterk. ${ }^{157}$ Det store skillet mellom svake og sterke adopsjoner kom ved 1979-loven, som trådte i kraft 1. januar 1980. I overgangsreglene i 1985-loven var det bestemt at for adopsjoner som var gitt før 1. januar 1980, skulle eldre lovgivning om arverett gjelde, med mindre en domstol etter søknad bestemte at de nye reglene skulle gjelde. ${ }^{158}$

En ny adopsjonslov ble vedtatt i Finland i 2012. ${ }^{159}$ Den nye loven har også overgangsregler som gir de svake adopsjonene mulighet til å kunne overleve nok en reform av adopsjonslovgivningen. Overgangsreglene innebærer at dersom arvelateren er død før 1. juli 2012, og domstolen hadde gitt samtykke til adopsjon før 1. januar 1980, beror arveretten for

\footnotetext{
${ }^{154}$ Adoptionsloven $1972 \S 39$ stk. 2.

${ }^{155}$ Lag 1971: 870.

${ }^{156}$ Se Urpo Kangas, Familje- och kvarlåtenskapsrättens grunder, Helsingfors 2015, s. 459.

${ }^{157}$ Lag om adoption (32: 1979) 12 § og adoptionslag (153:1985) 12 §.

${ }^{158}$ Marianne Hognestad og Knut R. Steenberg, Adopsjonsloven, Oslo 2000, s. 42.

${ }^{159}$ Adoptionslag (22:2012).
} 
barnet og barnets etterkommere på de reglene som gjaldt da samtykke til adopsjon ble gitt. ${ }^{160}$ Etter søknad fra barnet kan endring skje til reguleringen som følger av ny adopsjonslov. ${ }^{161}$ Hvis adopsjonen var etablert før 1. januar 1980, men arvelateren dør etter 1. juli 2012, vil barnets arverett etter adoptivforeldrene og deres slekt avgjøres etter adopsjonsloven av 2012. Barnet vil da være berettiget til arv etter adoptivforeldrene. Barnet har imidlertid også rett til arv etter de biologiske foreldrene og deres slektninger, men de biologiske foreldrene og deres slekt vil ikke lenger har rett til arv etter barnet. ${ }^{162}$

Sterk adopsjon ble innført på Island ved adopsjonsloven av 1978. Den gjeldende adopsjonsloven på Island er fra 1999. ${ }^{163}$ Denne loven bygger også på at barnet får samme rettigheter overfor adoptivforeldrene og deres slekt som adoptivforeldrenes biologiske barn, og at de juridiske båndene til den biologiske familien brytes, jf. lovens $\S 25$ første ledd. Ved stebarnsadopsjon får barnet stilling som om barnet var ekteparets felles biologiske barn. Det samme gjelder adopsjon av samboerens barn, jf. lovens $§ 25$ andre ledd.

\section{Oppsummering - avsluttende vurderinger}

\subsection{Blodsbånd, sosial tilhørighet og beskyttelse av barnet}

Blodsbåndet og det sosioøkonomiske bånd mellom arvelateren og dem som skal utpekes som arvinger, har vært fremhevet som avgjørende for slektsarveretten. I den svenske utredningen om arverett fra 1925 ble det uttrykt slik:

«Det naturliga blodsbandet är visserligen arvsrättens grund, såvitt skyldemäns arvsrätt angår, men icke såsom isolerat faktum, utan sådant det avspeglas i det allmänna föreställningssättet under inverkan jämväl av andra grunder, främst den samhörighet, som förenar medlemmarna av det å äktenskapet vilande familjen.» 164

Beskjæringen av slektsarverett har vært begrunnet i at både slektskapsbåndene og de sosioøkonomiske båndene avtar ut over i arvegangsklassene. Denne doble tilknytningen har vært et hinder på vegen mot å inkludere i den arverettslige familien både barn født utenfor ekteskap og barn som er adoptert. For barn som var født utenfor ekteskap, var blodsbåndet der, selv om det kunne være vanskelig å bevise det. De sosioøkonomiske båndene var likevel ofte fraværende mellom barnet og faren. Etter hvert som bidragsplikten ble mer omfattende, ble det sosioøkonomiske båndet styrket. Utviklingen i medisin gjorde det enklere å bevise blodsbåndet.

I adopsjonsforholdene mangler blodsbåndet mellom barnet og adoptivforeldrene, selv om de sosioøkonomiske båndene er der i fullt monn. Etter hvert trumfet de sosiale båndene de biologiske. Gjensidig arverett $i$ adopsjonsforhold kan nok ha en viss sammenheng med at ektefellens stadig sterkere arverettslige stilling viste at biologi ikke var en absolutt forutsetning for arverett.

Et paradoks når man ser på den parallelle utviklingen av arverett for barn født utenfor ekteskap og arverett mellom adoptivforeldre og barn som er adoptert, er at biologien og det

\footnotetext{
${ }^{160}$ Adoptionslag (22: 2012) $100 \S 1$. mom.

161 Adoptionslag (22: 2012) $99 \S 3$. mom.

162 Adoptionslag (22:2012) 100 § 3. mom. Se nærmere Urpo Kangas, Familje- och kvarlåtenskapsrättens grunder, Helsingfors 2015, s. 459-460.

${ }^{163}$ Lov 31. desember 1999 nr. 130.

${ }^{164}$ SOU 1925: 43 s. 103.
} 
ansvar det medfører å sette barn til verden, var en brekkstang for å gi barn født utenfor ekteskap arverett etter faren og farsslekten, mens man i adopsjonsforhold setter en strek over biologien og legger fullt fokus på de sosiale forholdene.

Løfter man blikket, er det nok likevel beskyttelse av barnet og barnets økonomi, sosiale tilhørighet og anerkjennelse i samfunnet som er de tyngste loddene i vektskålen for endringene både i adopsjonsforhold og for barn født utenfor ekteskap. Barn som var født utenfor ekteskap, levde ofte i dårlige kår. Både bidrag og arverett fra far kunne bøte på den vanskelige økonomiske situasjonen. Det ville også lette på det sosiale stigma som barna vokste opp under. I adopsjonsforhold var forholdet ofte det at barnet verken kjente til sitt biologiske opphav eller kunne vente særlig arv fra den biologiske slekten. Arverett etter adoptivforeldrene var derfor viktig både for å sikre barnets økonomiske fremtid og dets sosiale status både i adoptivfamilien og i samfunnet for øvrig.

\subsection{Norden i verden}

Utviklingen i Norden har ikke foregått i et vakuum. Beskjæring av slektsarveretten, arverett for barn født utenfor ekteskap og overgang fra svake til sterke adopsjoner er utviklingstrekk vi har sett i hele Europa i de siste 100 årene. Dels har utviklingen fulgt alminnelige strømninger i samfunnet, slik det er redegjort for i avsnittene ovenfor, men utviklingen kan ikke skje løsrevet fra de forpliktelsene som følger av Den europeiske menneskerettskonvensjon (EMK) og avgjørelser fra den Den europeiske menneskerettsdomstolen (EMD).

En hardhendt beskjæring av slektsarveretten vil kunne støte an mot retten til familieliv i EMK artikkel 8 - i hvert fall hvis den ikke kombineres med en forholdsvis sjenerøs adgang til å tilkjenne arv til slektninger som faller utenfor den arveberettigede kretsen, men hvor det har vært en familierelasjon i konvensjonens forstand mellom arvelateren og de etterlatte slektningene. Det er lite trolig at dagens avgrensning av kretsen av slektsarvinger støter an mot et slikt hinder. Det har heller ikke vært aktuelt med ytterligere beskjæringer. ${ }^{165}$

Hvis man skulle kutte ut også besteforeldre og arvinger i andre arvegangsklasse, ville spørsmålet bli satt mer på spissen. Hvor barn mister sine foreldre, stepper ofte besteforeldre og onkler og tanter inn som fosterforeldre. Det er heller ikke helt uvanlig at søsken bor sammen i voksen alder. Hvis slike familierelasjoner ikke skulle gi grunnlag for arv etter loven, kunne det bli et problem relatert til konvensjonen selv om man ville ha rett til å tilgodese hverandre gjennom testament. I EMDs storkammeravgjørelse 29. april 2008 Burden v. United Kingdom kom domstolen til at det ikke var diskriminerende at to søstre som bodde sammen, ble behandlet annerledes i arveavgiftsmessig sammenheng enn ektefeller og registrerte partnere som bodde sammen. Domstolen mente at det var relevante forskjeller i samlivet mellom søsken og dem som lever sammen i et parforhold. Hadde problemstillingen vært om søsken kunne avskjæres fra gjensidig arverett etter loven, ville spørsmålet vært mer i kjernen av retten til familieliv. I alle de nordiske landene er det ordninger som innebærer at nærstående kan få arv etter arvelateren selv om de faller utenfor den kretsen av arvinger som

\footnotetext{
${ }^{165}$ I Utkast til lov om arv 1963 gikk imidlertid flertallet inn for å utvide arveretten slik at også tredje arvegangsklasse skulle gå uendelig langt nedover i generasjonene (se s. 39-46). Det er også tatt til orde for igjen å utvide tredje arvegangsklasse til å omfatte fettere og kusiner, se Anders Agell, «Bör kusiner få ärva?», i Familjerättsliga studier. Vänbok till Åke Salden, Stockholm, 2003, s. 9 flg.
} 
loven uttrykkelig utpeker som arvinger. ${ }^{166}$ Dette gir en sikkerhetsventil for tilfeller hvor lovens avgrensning av arvinger ellers ville kunne lede til støtende resultater.

At barn født utenfor ekteskap skal ha samme arverett etter sine foreldre som barn født innenfor ekteskap, er flere ganger slått fast av EMD. Forskjellsbehandling av barn født henholdsvis innenfor og utenfor ekteskap med hensyn til arverett etter foreldrene har blitt ansett som krenkelse av konvensjonens artikkel 8 om retten til respekt for privatliv og familieliv, sammenholdt med forbudet i artikkel 14 mot diskriminering. ${ }^{167}$ Da disse sakene kom opp for domstolen i Strasbourg, hadde lovgivningen allerede blitt endret i alle de nordiske landene. Imidlertid tok domstolen et nytt skritt i dommen av 9. februar 2017 Mitzinger mot Tyskland, hvor EMD fant overgangsregler for arverett etter faren for barn som var født utenfor ekteskap, diskriminerende. Tyskland hadde innført lik arverett for barn født innenfor og utenfor ekteskap i 1969, men lovendringen ble ikke gitt virkning for barn som var født før 1949. Klageren, som var født i 1940, fikk medhold i at de tyske reglene innebar en krenkelse av artikkel 14, sammenholdt med artikkel 8.

Mitzinger skaper neppe problemer for norsk og dansk rett, hvor likestillingen ble gjennomført for så lenge siden at det neppe er mange tilfeller hvor fraværet av arverett etter faren og farsslekten skaper problemer i dag. At arveretten etter farsslekten var begrenset i Danmark frem til 1963, kan likevel skape problemer i arveoppgjør hvor barnet skulle vært arving i andre eller tredje arvegangsklasse. På Island ble det slått fast av Høyesterett allerede i 1951 at likestillingen arverettslig av barn født utenfor ekteskap hadde tilbakevirkende kraft.

Finland, som var sist ute med å likestille barn født innenfor og utenfor ekteskap, fikk tilsvarende problemer som Tyskland allerede noen år tidligere. Finlands Högsta domstolen kom i sak 2012:11 til at barn født utenfor ekteskap hadde arverett etter sin far selv om barnet var født utenfor ekteskap før 1976. Dommen kom i kjølvannet av flere avgjørelser mot Finland fra EMD ${ }^{168}$ I faderskapslagen av 2015, som trådte i kraft i 2016, ble dette også gjennomført i lov. Det ble i faderskapslagen 67 § åpnet for arverett for barn født før 1976, men arverett forutsatte som hovedregel at arvelateren var død før 31. januar 2012. Også i tilfeller hvor arvelateren var død før 31. januar 2012, kunne barnet få arverett dersom arven ellers tilfalt staten, eller tap av arverett ville gi urimelige utslag innad i en søskenflokk. ${ }^{169}$

I Sverige ble reglene om arverett for barn født utenfor ekteskap gitt tilbakevirkende kraft. ${ }^{170}$ Det er likevel andre og ganske korte preskripsjonsregler som gjelder for barn født utenfor ekteskap, i tilfeller hvor barnet var ukjent for de øvrige arvingene. Det kan tenkes at barn som går glipp av arverett etter faren og farsslekten på grunn av disse særlige preskripsjonsfristene, vil kunne ha en god sak for EMD. I Sverige er det ikke gjort endringer i overgangsreglene for arverett i kjølvannet av de finske avgjørelsene og Mitzinger mot Tyskland.

\footnotetext{
${ }^{166}$ Se norsk arvelov $\S 76$ andre ledd; dansk arvelov $§ 92$ stk. 2.; islandsk arvelov $§ 55$ andre ledd; lag (2021:410) om Allmänna arvsfonden $10 \S$ (Sverige); finsk ärvdabalk 5. kap. 2 .

${ }^{167}$ Se EMDs dommer 13. juni 1979 Marckz mot Belgia (diskriminering av barn født utenfor ekteskap med hensyn til arverett etter moren og morsslekten); 28. oktober 1987 Inze mot $\emptyset$ sterrike (diskriminering av barn født utenfor ekteskap med hensyn til retten til å overta landbrukseiendom); 29. november 1991 Vermeire mot Belgia (diskriminering av barn født utenfor ekteskap med hensyn til arverett etter farsslekten); og 1. februar 2000 Mazurek mot Frankrike (diskriminering av barn som var unnfanget med utroskap, med hensyn til arverett etter moren som hadde vært utro).

${ }^{168}$ Dommer 6. juli 2010 Grönmark mot Finland, Backlund mot Finland. Senere har dommene av 15. januar 2013 Laakso mot Finland og 29. januar 2013 Röman mot Finland gått i samme retning.

${ }^{169}$ Se RP 91/2014 s. 65-66 og s. 71-72.

${ }^{170}$ Se nærmere punkt 3.5 ovenfor.
} 
Når det gjelder adopsjon, har det ikke vært samme sakstilfang for EMD som i saker om arverett for barn født utenfor ekteskap. I EMDs dom 13. juni 2004 Pla og Puncernau mot Andorra kom imidlertid domstolen til at en testamentstolkning fra en andorransk ankedomstol som kom til at formuleringen i et testament om «sønn eller sønnesønn» ikke omfattet en sønnesønn som var adoptert, var i strid med diskrimineringsforbudet i konvensjonen. ${ }^{171}$ Det er ikke umulig at man vil kunne komme til at det er konvensjonsstridig dersom barn blir stående uten arverett på grunnlag av eldre, svake adopsjoner. Det vil nok fortsatt være enkelte tilfeller hvor dette kan bli satt på spissen, særlig i Finland, Island og Danmark, som var relativt sent ute med full overgang til sterke adopsjoner.

\footnotetext{
${ }^{171}$ Nærmere om dommen, se Karl Harald Søvig, «Arverettslig diskriminering av adoptivbarn testamentstolkning i Strasbourg», FAB 2006, s. 299 flg.
} 